\title{
Human Papillomavirus Type 16 in Head and Neck Carcinogenesis
}

\author{
Ren Wei Chen
}

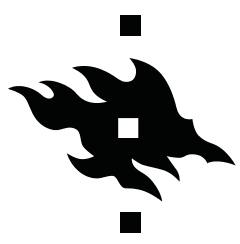

UNIVERSITAS HELSINGIENSIS

HELSINKI 2004 


\title{
Human Papillomavirus Type 16 in Head and Neck Carcinogenesis
}

\section{Ren Wei Chen}

\author{
Department of Virology \\ Haartman Institute \\ and \\ Department of Otorhinolaryngology - \\ Head and Neck Surgery \\ Helsinki University Central Hospital \\ University of Helsinki \\ Finland
}

\begin{abstract}
Academic Dissertation
To be publicly discussed, with the permission of the Faculty of Medicine of the University of Helsinki, in the Small Lecture Hall, Haartman Institute, on June $18^{\text {th }}$ at 12 o $^{\prime}$ clock noon.
\end{abstract}

Helsinki, 2004 


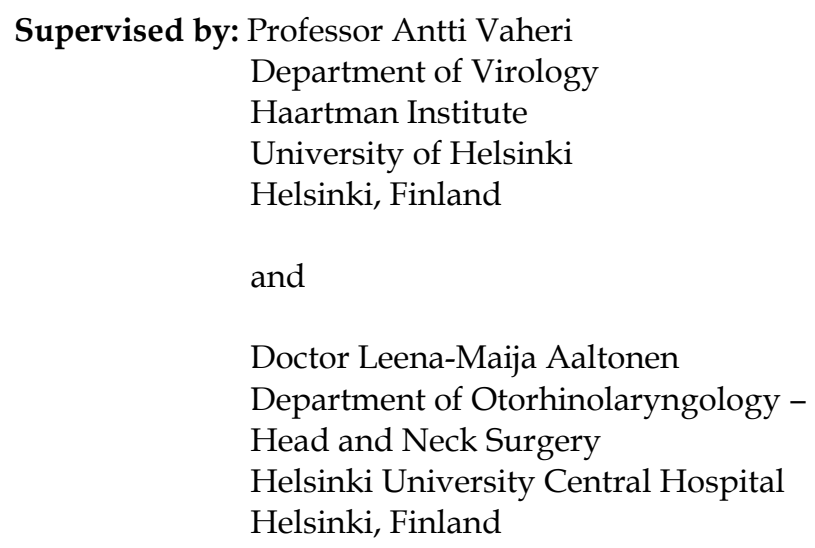

Reviewed by: Professor Stina Syrjänen

Department of Oral Pathology and Radiology

Institute of Dentistry

University of Turku

Turku, Finland

and

Professor Reidar Grenman

Department of Otorhinolaryngology -

Head and Neck Surgery

Turku University Central Hospital

Turku, Finland
Opponent: Doctor Peter J.F. Snijders
Department of Pathology
Vrije Universiteit Medical Center
Amsterdam, The Netherlands

ISSN 1457-8433

ISBN 952-10-1911-5 (Paperback)

ISBN 952-10-1912-3 (PDF)

http://ethesis.helsinki.fi

Edita Prima Oy

Helsinki, 2004 


\section{TABLE OF CONTENTS}

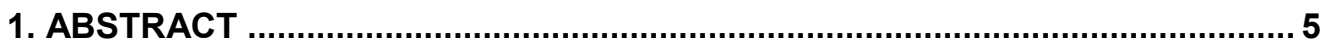

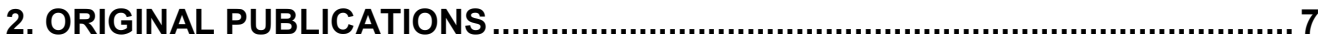

3. ABBREVIATIONS AND DEFINITION OF SOME ESSENTIAL TERMS................ 8

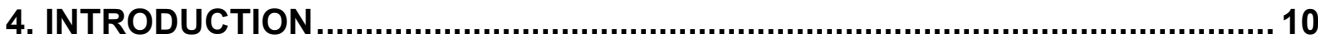

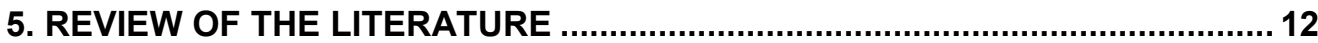

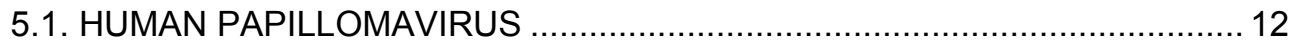

5.1.1. Classification of human papillomaviruses ............................................. 13

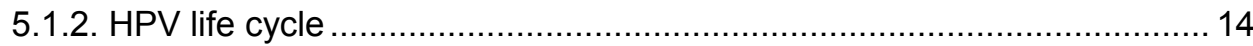

5.1.3. Function of viral proteins ……............................................................ 14

5.2. HISTORICAL BACKGROUND OF HPV AND CANCER ............................ 18

5.3. PTEN AND LKB1 TUMOR SUPPRESSOR GENES .................................. 18

5.4. SQUAMOUS CELL CARCINOMA OF THE HEAD AND NECK.................... 19

5.4.1. Etiology and risk factors for the head and neck cancer ......................... 20

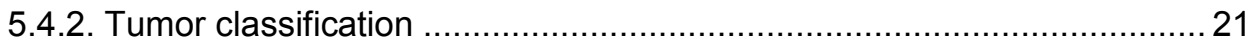

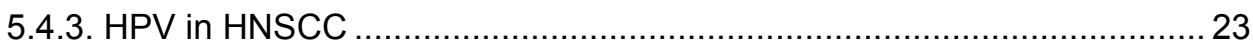

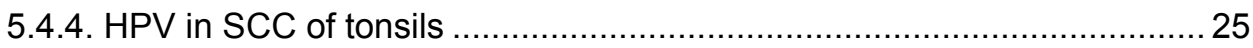

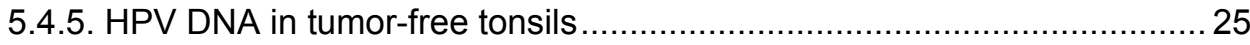

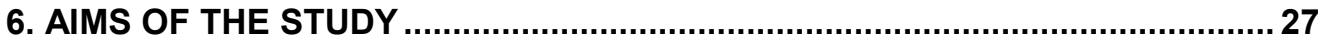

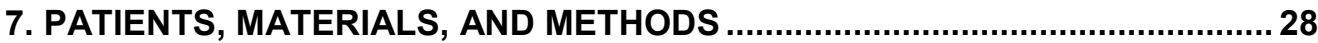

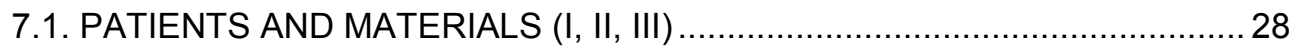

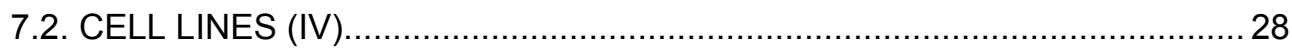

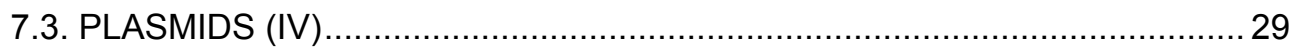

7.4. METHODS

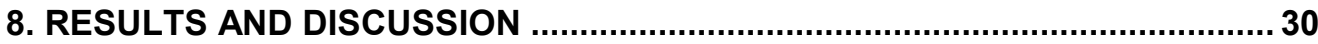

8.1. SOMATIC MUTATION IN PTEN AND LKB1 GENES IS A RARE EVENT IN

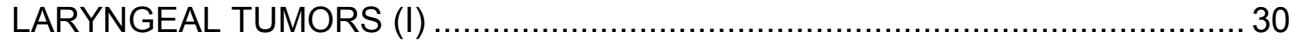

8.2. PREVALENCE AND PHYSICAL STATUS OF HPV IN HNSCC (II) ...............31

8.2.1. Prevalence, genotype, viral load, and physical status of HPV DNA in

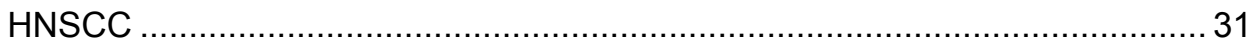

8.2.2. Absence of viral capsid protein expression in HNSCC.......................... 33

8.2.3. Correlation of HPV DNA status and clinical outcome ..............................34 
8.3. PRESENCE OF HPV-16 DNA BUT NO OTHER TYPES IN TUMOR-FREE

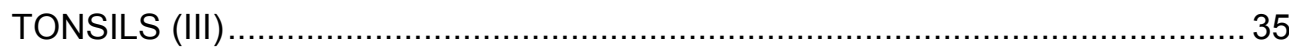

8.3.1. Presence of HPV DNA and HPV genotypes in tumor-free tonsils ........... 35

8.3.2. Seroprevalence of antibodies against HPV-16 L1, E6, and E7 ............. 36

8.3.3. Non-concordance between presence of HPV DNA in tonsillar tissue and seropositivity to HPV proteins

8.4. ESTABLISHMENT AND CHARACTERIZATION OF HPV-16 DNA

IMMORTALIZED HUMAN TONSILLAR EPITHELIAL CELL LINES (IV) 37

8.4.1. Growth and differentiation of HPV-16 DNA transfected human tonsillar epithelial cells 37

8.4.2. Tumorigenicity of HPV-16 transformed cell lines................................... 38

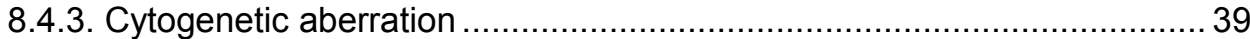

8.4.4. Physical status and chromosomal localization of viral DNA in HPV-16 transformed HTE cell lines

8.4.5. Viral gene expression in HPV-16 transformed HTE cell lines. 41

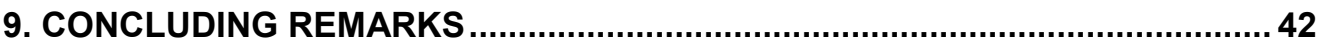

10. PERSPECTIVES

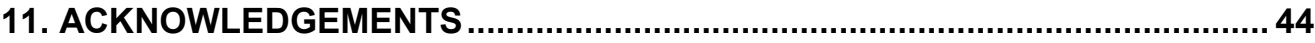

12. REFERENCES 


\section{ABSTRACT}

The etiology of squamous cell carcinomas of the head and neck (HNSCC) is considered to be multifactorial. Besides the main risk factors of tobacco and alcohol, infection by human papillomavirus (HPV) and genetic alterations are likely to play a role. Oncogenic HPVs are a causative agent in uterine cervical cancer, and molecular biology approaches have provided evidence for specific mechanisms. The role of HPV infection in head and neck carcinogenesis is less well established. HPV DNA has been repeatedly detected in HNSCC, especially in squamous cell carcinomas of tonsils. Little is known about HPV infection in tumor-free tonsils.

To investigate the role of tumor suppressor genes, PTEN and LKB1, in laryngeal tumorigenesis, we analyzed somatic mutations of these genes from laryngeal carcinoma and laryngeal papillomatosis by genomic sequencing and single strand confirmation polymorphism assay, respectively. We observed no mutation in these two genes in our studied samples.

In an attempt to elucidate HPV status in head and neck carcinomas, we studied the frequency of HPV DNA and viral genotypes in HNSCC by means of SPF10 PCR and INNO-LiPA hybridization. We found that more than half the patients harbored HPV DNA in their HNSCC samples, and oncogenic HPV-16 was predominant. Copy numbers of viral E2 and E6 genes in the HPV-16 positive HNSCC samples were quantitated by real-time PCR. We observed a considerable variation in the viral copy numbers among different samples, and tonsillar carcinomas had a remarkably higher viral load than did carcinomas in the other sites of the head and neck region. HPV-16 existed in episomal, integrated, or mixed forms and tumors harboring only episomal virus were significantly larger in size at diagnosis than those with only integrated or mixed forms. The presence of HPV DNA did not correlate with a better prognosis in HNSCC patients.

Furthermore, we also observed that $6 \%$ of patients with tonsillitis or tonsillar hypertrophy harbored oncogenic HPV-16 but no other types in their tonsillar tissue, as determined by a sensitive nested PCR assay. The presence of HPV-16 DNA in tonsils did not correlate with serum antibodies against viral proteins. Our findings imply that tonsillar epithelial cells serve as a reservoir for HPV-16 virus. 
To establish an in vitro model to study mechanisms involved in HPV-associated tonsillar carcinogenesis, normal human tonsillar epithelial (HTE) cells were transfected with full-length HPV-16 DNA. All the transfected HTE cell lines were cytogenetically abnormal. They exhibited altered morphology and impaired expression of cytokeratins in organotypic culture. They failed to form colonies in soft agarose and formed no tumors in nude mice within 6 months. They have been cultured over 100 passages and considered as immortalized cell lines and thus provide a useful model for studying further the multistep molecular events of HPV16 associated tonsillar carcinogenesis. 


\section{ORIGINAL PUBLICATIONS}

This thesis is based on the following original studies, which are referred to in the text by their Roman numerals.

I. Chen RW, Avizienyte E, Roth S, Leivo I, Mäkitie AA, Aaltonen L-M, Aaltonen LA. PTEN and LKB1 genes in laryngeal tumors. J Med Genet 1999; 36; 943-4.

II. Koskinen $W^{*}$, Chen RW*, Leivo I, Mäkitie A, Bäck L, Kontio R, Suuronen R, Lindqvist C, Auvinen E, Molijn A, Quint WG, Vaheri A, Aaltonen L-M. Prevalence and physical status of human papillomavirus in squamous cell carcinomas of the head and neck. Int J Cancer 2003; 107; 401-6. *These two authors contributed equally to this article.

III. Chen RW, Sehr P, Waterboer T, Pawlita M, Leivo I, Vaheri A, Aaltonen L-M. Presence of DNA of human papillomavirus 16 but no other types in tumor-free tonsillar tissue. Resubmitted (J Clin Microbiol)

IV. Chen RW, Aalto Y, Teesalu T, Dürst M, Knuutila S, Aaltonen L-M, Vaheri A. Establishment and characterization of human papillomavirus type 16 DNA immortalized human tonsillar epithelial cell lines. Eur J Cancer 2003; 39; 698707.

The original publications are reproduced with the permission of the copyright holders. 


\section{ABBREVIATIONS AND DEFINITION OF SOME ESSENTIAL TERMS}

AJC

ATCC

DEIA

$\mathrm{E}$

EGF

FISH

HES

HNSCC

HPV

HTE

IARC

IHC

ISH

$\mathrm{kb}$

L

LiPA

MMAC

NCR

ORF

PBS

PCR

PTEN

SCC

SPF

SSCP

LKB1/STK11

UICC

VLP
American Joint Cancer Committee

American Type Culture Collection

DNA enzyme immunoassay

early (gene)

epidermal growth factor

fluorescence in situ hybridization

human embryonic skin

squamous cell carcinoma of the head and neck

human papillomavirus

human tonsillar epithelium

International Agency for Research on Cancer

immunohistochemistry

in situ hybridization

kilobase(s)

late (gene)

line probe assay

mutated in multiple advanced cancers

non-coding region

open reading frame

phosphate-buffered saline

polymerase chain reaction

phosphatase and tensin homolog gene

squamous cell carcinoma

short PCR fragment

single strand confirmation polymorphism

serine/threonine kinase 11

International Union Against Cancer

virus-like particle 
EPISOMAL VIRUS - viral DNA exits extrachromosomally in a cell.

INTEGRATED VIRAL GENOME - a viral genome which is incorporated into the cellular DNA and is replicated with it.

INTEGRATION - the process of insertion of viral DNA into the host genome. It usually involves a virus-coded enzyme, the integrase. The viral DNA is then replicated by the host nucleic acid replication mechanism.

TRANSFECTION - Two different approaches serve to transfer DNA into eukaryotic cells: transient transfection and stable transfection. In transient transfection, recombinant DNA is introduecd into a recipient cell line in order to obtain a temporarily but high level of expression of the target gene. The transfected DNA does not necessarily become integrated into the host chromosome. Stable transfection is used to establish clonal cell lines in which the transfected target gene is integrated into chromosomal DNA.

FISH - This procedure describes fluorescence in situ hybridization of biotin- or digoxygenin-labeled probes to denatured metaphase chromosomes and interphase nuclei. The hybridized probes are detected and visualized with fluorochromeconjugated reagents. 


\section{INTRODUCTION}

The etiology of squamous cell carcinomas of the head and neck (HNSCC) is considered to be multifactorial. Besides the main risk factors, tobacco use and alcohol intake (Decker and Goldstein 1982; Franceschi et al 1990), infection by oncogenic human papillomavirus (HPV) as well as genetic alterations are likely to play a role in it. Several tumor suppressor genes play a role in human tumorigenesis. Somatic mutations of the PTEN gene, a major new tumor suppressor gene located at human chromosome 10q23, have been found in several types of cancers, including gliomas and glioblastoma, as well as carcinomas of prostate, kidney, and breast (Daniel et al 1995; Fallani et al 1997; Steck et al 1997). Germline mutations in $L K B 1$, a tumor suppressor gene mapped to 19p13.3, have been associated with Peutz-Jeghers syndrome (PJS) (Hemminki et al 1998; Jenne et al 1998) whereas somatic mutations in this gene are a rare event in most sporadic tumors (Avizienyte et al 1998; Avizienyte et al 1999; Bignell et al 1998; Park et al 1998; Resta et al 1998). Little is known about the role of PTEN and LKB1 genes in the development of laryngeal tumors, among which approximately $25 \%$ (range 0 to $100 \%$ ) of laryngeal carcinomas are associated with infection of oncogenic HPVs and 83 to $100 \%$ of the laryngeal papillomatosis are associated with infection by HPV types 6 or 11 (Syrjänen and Syrjänen 2000; Aaltonen et al 2002).

HPVs are small double-stranded DNA viruses infecting epithelial cells of the skin, as well as anogenital and oropharyngeal mucosa. To date, 96 HPV genotypes have been identified and fully sequenced (de Villiers et al 2004). An increasing number of studies have reported on the presence of HPV in HNSCC; its frequency varies greatly, depending on the number of patients included and tumor site, as well as detection methods applied. By a sensitive PCR, the overall prevalence of HPV DNA in HNSCC has been reported from 9 to $60 \%$ and the majority of HPVpositive tumors contained the high-risk HPV-16 (Snijders et al 1996; Paz et al 1997; McKaig et al 1998; Gillison et al 2000; Mork et al 2001). Sero-epidemiological data showed that a significantly increased risk of HNSCC is associated with HPV-16 seropositivity (Schwartz et al 1998; Mork et al 2001; Herrero et al 2003). The prevalence of HPV, particularly the high-risk types, suggests a causal association 
between HPV and a subset of HNSCC (Gillison et al 2000; Herrero et al 2003; Dai et al 2004; Smith et al 2004). HPV is more commonly found in squamous cell carcinoma (SCC) of the tonsil than at other sites of HNSCC (Snijders et al 1992; Paz et al 1997; Klussmann et al 2001; Mellin et al 2000). The reason for the close association of HPV with tonsillar SCC remains unclear. Investigation of HPV infection in the tumor-free tonsils would additionally elucidate the role of HPV in tonsillar carcinogenesis.

Oncogenic HPVs play an etiological role in cervical cancer, and molecular biological approaches have provided evidence for specific carcinogenic mechanisms. Besides the most-studied tumor suppressor proteins p53 and pRb, which are degraded by the viral oncoproteins E6 and E7, respectively, several other cellular proteins have also been found to interact with these two viral oncoproteins (Mantovani and Banks 2001; Munger et al 2001; Scheffner and Whitaker 2003). Study of HPV in cell culture has been hindered because a complete viral life cycle cannot be mimicked in vitro. Although terminal differentiation of squamous epithelial cells has been achieved by use of a raft culture system, infectious virion production is very limited (Meyers et al 1992; Meyers et al 2002). Transfection of primary human epithelial cells with high-risk types of HPV DNA often results in cell transformation and immortalization (McDougall 1994). The HPV-immortalized cell lines such as human cervical epithelial cells and foreskin keratinocytes, as well as the naturally infected cell lines UT-Dec-1 and W-12 have served as an in vitro model for studying the role of HPV in human carcinogenesis (Dürst et al 1987a; Stanley et al 1989; Zheng et al 1994; Hietanen et al 1998). To establish an HPV-immortalized tonsillar epithelial cell line may provide a useful in vitro model to study HPV in tonsillar carcinogenesis. 


\section{REVIEW OF THE LITERATURE}

\subsection{HUMAN PAPILLOMAVIRUS}

Human papillomaviruses (HPVs) belong to the Papillomaviridae family and are small, nonenveloped, icosahedral DNA viruses. The viral particles are 55 to $60 \mathrm{~nm}$ in diameter and consist of a single molecule of a double-stranded covalently closed circular DNA genome of approximately $7900 \mathrm{bp}$. The genomic organization of all papillomaviruses is remarkably similar (Fig 1). Viral DNA is associated with cellular histones to form a chromatin-like complex. All coding sequences are located on one DNA strand only. Most papillomaviruses contain six early ORFs and two late ORFs. There is a region with no ORFs which is designated the long control region (LCR), the upstream regulatory region (URR), or the noncoding region (NCR).

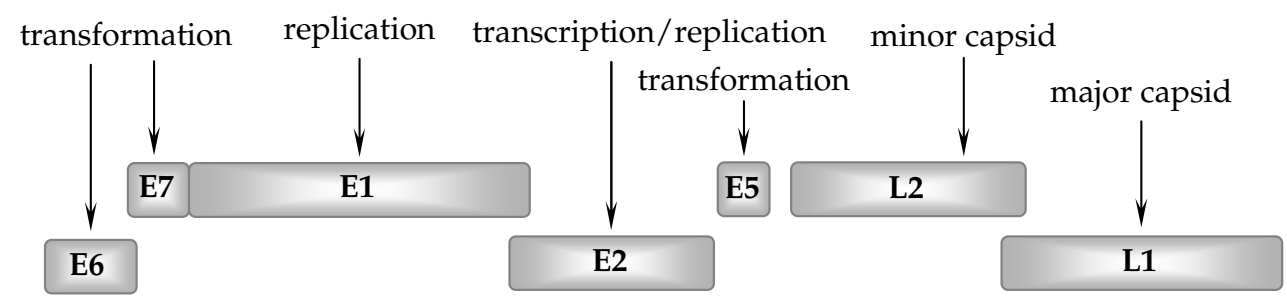

\section{E4}
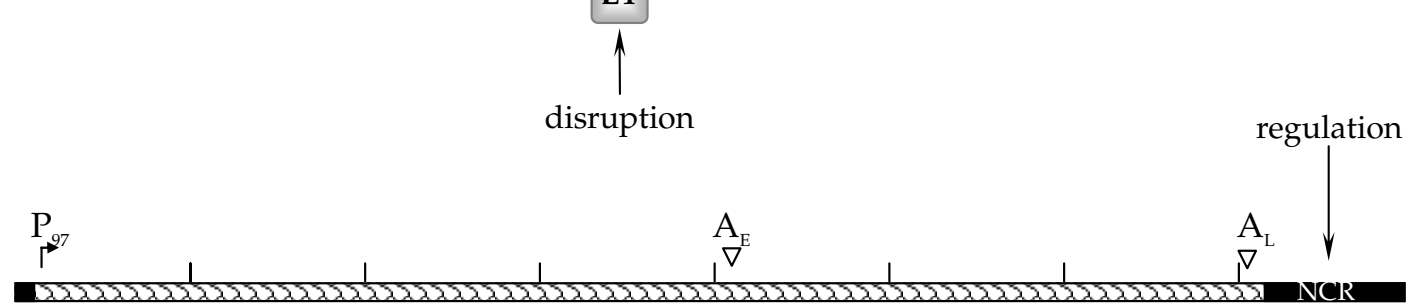
1000 2000 3000 4000 5000 6000 7000 7904 bp

Figure 1. Genomic organization of HPV-16. ORFs deduced from the DNA sequence are designated E1 to E7, L1, and L2, indicated in grey boxes. A non-coding region (NCR) is indicated by a black box. Main functions of genes are listed. 


\subsubsection{Classification of human papillomaviruses}

\section{Genotypes}

Determination of HPV genotypes is based on their degree of homology within the L1 ORF (de Villiers 1997). If the DNA sequence of the L1 ORF of a new isolate differs by more than $10 \%$ from the closest related known type, it is regarded as a novel type; a difference between 2 and 10\% is referred to as a subtype; and at less than $2 \%$, a variant, as agreed at the International Papillomavirus Workshop held in Quebec in 1995 (zur Hausen 1996). Thus far, 96 HPV genotypes have been fully sequenced and identified (de Villiers et al 2004).

\section{Mucosal and cutaneous types}

Depending on the location of the lesion from which a specific HPV type was first isolated, HPV can be classified as mucosal or cutaneous types. HPV types associated with skin warts are for example HPV-1, -2, and -4 . A wide range of HPV types including HPV-5, -8, -9, -23, and -47 cause epidermodysplasia verruciformis lesions, which can be transformed to malignancy upon exposure to ultraviolet light (Androphy 1994; Pfister 2003). The largest subgroup is represented by HPV types infecting mainly mucosal surfaces of the genital and respiratory tracts. More than 40 of the identified HPV types belong into this group (de Villiers 1997).

\section{High-and low-risk types}

Classification of HPVs can be extended to cover the carcinogenic potential of different virus types. According to a recent publication by Munoz and colleagues, 15 are classified as high-risk types including HPV-16, -18, -31, -33, -35, -39, -45, -51, $-52,-56,-58,-59,-68,-73$, and $-82 ; 3$ are classified as probable high-risk types which are HPV-26, -53, and -66; low-risk types consist of HPV-6, -11, -40, -42, -43, 44, -54, -61, -70, -72, -81, and CP6108 (Munoz et al 2003). 


\subsubsection{HPV life cycle}

HPV has a specific tropism for squamous epithelial cells. Several modes of viral DNA replication during the infection were suggested in a review (Chow and Broker 1994) and are elucidated in Fig 2. Thus, HPV proteins stimulate the proliferation of cells and interfere with normal epithelial cell differentiation, leading to an increased thickness of the infected epithelial cells which produces neoplasia.

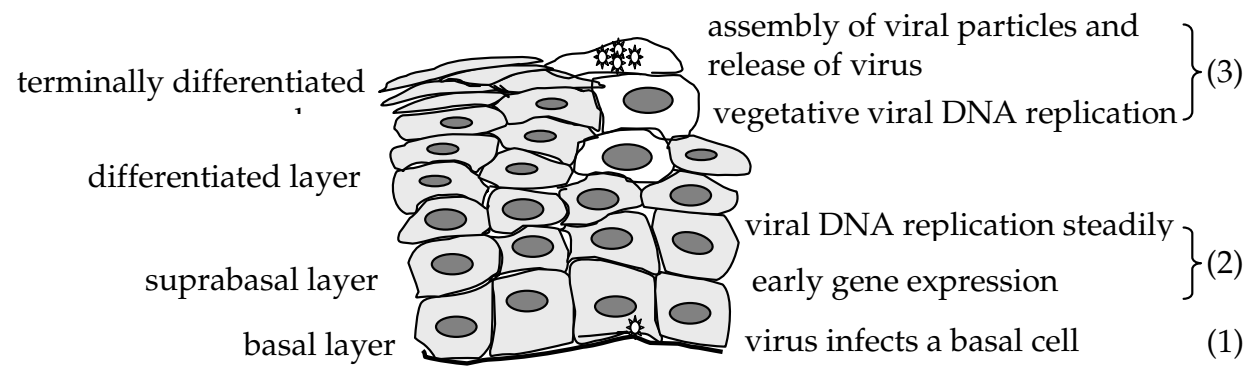

Figure 2. Schematic representation of HPV life cycle in stratified epithelium. (1) HPV infects basal cells of the squamous epithelium through microabrasions, and wound-healing promotes the proliferation of basal cells and activates the expression the viral early genes, resulting in a temporary amplification of the viral DNA; (2) after wound healing, most basal cells return to a quiescent state and divide infrequently, and viral transcription and replication are autoregulated at a low level, resulting in a steady-state, low-level maintenanence mode; (3) after a cell leaves the cell cycle and undergoes progressive differentiation, a vegetative amplification mode for the production of progeny virus occurs.

\subsubsection{Function of viral proteins}

\section{E1 and E2 proteins}

The E1 protein has site-specific DNA-binding functions and it binds to the origin of replication in the NCR (Ustav et al 1991; Holt et al 1994). The E2 open reading frame (ORF) encodes at least two or three different proteins which all act as transcription factors and regulate viral transcription (Cripe et al 1987; Baker et al 1987; Bouvard et al 1994). The E2 proteins bind to the E1 and stimulate viral DNA 
replication (Chow and Broker 1994). During early stages of viral infection, the E2 protein represses transcription of the oncogenes E6 and E7 (Thierry and Howley 1991). Integration of the viral genome, which often takes place during carcinogenic progressing, disrupts the E2 and E1 ORFs and results in elevated expression of E6 and E7 (Jeon and Lambert 1995).

\section{E4 protein}

The E4 ORF is located in an early gene region, yet it appears to be expressed as a late gene with a role in productive infection. It is exclusively localized within the differentiating layer of the infected epithelium and induces the collapse of the cytokeratin network (Doorbar et al 1991; zur Hausen 1996).

\section{E5 protein}

The E5 of HPV-16 is a small hydrophobic polypeptide and with weak transforming activity (Leptak et al 1991; Pim et al 1992). The E5 ORF is often disrupted in cervical cancer and does not seem to be essential for maintaining the malignant phenotype but is possibly important for initiation of transformation (Schwarz et al 1985; zur Hausen 1996). The E5 stimulates the transforming activity of the epidermal growth factor receptor resulting in increased cell proliferaction (Pim et al 1992). In a raft culture model, the E5 was shown to support cellular DNA synthesis in suprabasal cells and neither viral late gene expression nor epithelial differentiation was affected by the E5 (Genther et al 2003). The E5 protects human foreskin keratinocytes from ultraviolet B-irradiation-induced apoptosis (Zhang et al 2002). On the other hand, it sensitizes human keratinocytes to apoptosis induced by osmotic stress (Kabsch and Alonso 2002).

\section{E6 protein}

The E6 protein of HPV-16 is a small polypeptide of approximately 150 amino acids. It contains two zinc-binding domains, each of which contains two copies of a Cys-X-X-Cys motif (Barbosa et al 1989). The E6 protein first binds to a cellular ubiquitin-ligase, the E6-associated protein (E6-AP) forming a complex which is 
then able to bind the p53 protein, resulting in p53 degradation mediated by the cellular ubiquitin proteolysis system (Werness et al 1990; Scheffner et al 1990; Scheffner et al 1993). Because p53 is required for the growth arrest following cellular DNA damage, cells without functional p53 are not arrested appropriately in G1, but display genomic instability (Werness et al 1990). The HPV-16 E6 protein activates telomerase (Klingelhutz et al 1996), an enzyme that maintains the telomeric DNA at the ends of linear chromosomes (Greider and Blackburn 1985). Without telomerase, telomers shorten upon each cell division, until they reach a critically short length. Beyond this point further division would induce damage in the coding regions of the chromosome and cause cell senescence. Telomerase activity is undetectable in most normal human somatic cells, but nearly all human cancers and immortalized cell lines have highly active telomerase (Kim et al 1994; Shay and Bacchetti 1997). Besides the p53 and telomerase, the E6 proteins also interact with various cellular proteins (Table 1).

\section{E7 protein}

The E7 protein of HPV-16 is a small, predominantly nuclear polypeptide of approximately 100 amino acids. Interestingly, the carboxy terminus of E7 contains a similar zinc-binding domain as the E6. The E7 binds to retinoblastoma protein $(\mathrm{pRB})$ and the related pocket proteins p107 and p130, results in releasing the transcription factor E2F from $\mathrm{pRB}$ complexes, and consequently activating genes regulating cell proliferation (Dyson et al 1989; Bagchi et al 1990; Bandara et al 1991). Besides the $\mathrm{pRb}$, the $\mathrm{E} 7$ also interacts with various proteins (Table 1), most of which are important regulators of cell growth, expecially the transition of a cell from the G1 to the S-phase of mitosis. The E7 protein has recently been shown to induce abnormal centrosome duplication, resulting in multipolar, abnormal mitoses, aneuploidy, and genomic instability, one of the hallmarks of a cancer cell (Duensing et al 2000; Duensing et al 2001). This function of E7 as a mitotic mutator may directly contribute to generating the host chromosomal changes that are necessary for carcinogenic progression of a high-risk HPV positive precursor lesion. 
Table 1. List of HPV-16 oncoproteins associated cellular proteins

\begin{tabular}{|c|c|c|}
\hline $\begin{array}{c}\text { Viral } \\
\text { oncoproteins }\end{array}$ & Cellular proteins & Reference \\
\hline \multirow{8}{*}{ E6 } & E6-associated protein, p53 & $\begin{array}{l}\text { Werness et al 1990; Scheffner and } \\
\text { Whitaker } 2003\end{array}$ \\
\hline & telomerase & Klingelhutz et al 1996 \\
\hline & hTERT & $\begin{array}{l}\text { Kiyono et al 1998; Gewin and Galloway } \\
2001\end{array}$ \\
\hline & homolog of disc large (hDlg) & $\begin{array}{l}\text { Lee et al 1997; Kiyono et al 1997; Gardiol } \\
\text { et al } 1999\end{array}$ \\
\hline & human Scribble (Vartul) & Nakagawa and Huibregtse 2000 \\
\hline & MUPP1 & Lee et al 2000 \\
\hline & MAGI-1, $-2,-3$ & Glaunsinger et al 2000; Thomas et al 2002 \\
\hline & Myc & Veldman et al 2003 \\
\hline \multirow{6}{*}{ E7 } & pRb, p107, p130 & $\begin{array}{l}\text { Dyson et al 1989; Bagchi et al 1990; } \\
\text { Bandara et al 1991; Scheffner and } \\
\text { Whitaker } 2003\end{array}$ \\
\hline & $\begin{array}{l}\text { AP-1 transcription factors (c- } \\
\text { Jun, JunB, JunD, c-Fos) }\end{array}$ & Antinore et al 1996 \\
\hline & $\begin{array}{l}\text { cyclin-dependent kinase } \\
\text { inhibitors (p21, p27) }\end{array}$ & $\begin{array}{l}\text { Funk et al 1997; Zerfass-Thome et al 1996; } \\
\text { Jones et al } 1997\end{array}$ \\
\hline & $\begin{array}{l}\text { histone deacetylases } \\
\text { complexes (HDAC) }\end{array}$ & Brehm et al 1999 \\
\hline & cyclins and Cdks & Chakrabarti and Krishna 2003 \\
\hline & pCAF & Avvakumov et al 2003 \\
\hline
\end{tabular}

Both E6 and E7 proteins play a role in cell transformation and immortalization. The E6 protein alone cannot immortalize human foreskin keratinocytes (Halbert et al 1991), but it is capable of immortalizing human mammary epithelial cells (Band et al 1991; Band et al 1993; Liu et al 1999) and inducing carcinomas in transgenic mice (Song et al 1999). The E7 alone is capable of immortalizing human foreskin keratinocytes (Halbert et al 1991). However, the E6 and E7 together can immortalize human epithelial cells cooperatively (Hawley-Nelson et al 1989; Munger et al 1989). In E6- and E7-transgenic mice experiments, the E7 primarily causes tumor promotion, whereas the E6 contributes weakly to the early stages, acts more strongly during tumor progression, and accelerates the malignant conversion of benign tumors (Song et al 2000). 
Late proteins

The L1 and L2 proteins are 72 capsomers encapsidating viral DNA. The L1 is the major capsid protein, with an average molecular mass of $57 \mathrm{KDa}$, and it contains reactive epitopes for type-specific neutralization. The L2 protein is a minor component of the viral capsid with an about $78 \mathrm{kDa}$ polypeptide (Doorbar and Gallimore 1987).

\subsection{HISTORICAL BACKGROUND OF HPV AND CANCER}

The hypothesis of infectious etiology of the common wart was shown by Ciuffo, who demonstrated in 1907 that cell-free extracts from common warts were transmissible from person to person upon intradermal inoculation, as reviewed in (zur Hausen 1999a). Papillomavirus as a carcinogen was first reported by Drs. Rous and Beard in 1934 (zur Hausen 1999a). It was not until the mid 1970s that HPV was singled out to be the most likely candidate for the cause of cervical cancer (zur Hausen et al 1974; zur Hausen 1976), and from 1983 to 1986, HPV-16, $18,-31$, and -33 were isolated from cervical cancer and its precursors (Dürst et al 1983; Boshart et al 1984; Lorincz et al 1986; Beaudenon et al 1986). In 1995, the International Agency for Research on Cancer (IARC) concluded that there was sufficient evidence to categorize HPV types 16 and 18 as human carcinogens (IARC 1995). An association between HPV and a subset of head and neck cancer was noticed already in the 1980s (Syrjänen et al 1982; Syrjänen et al 1983a; Löning et al 1985; de Villiers et al 1985).

\subsection{PTEN AND LKB1 TUMOR SUPPRESSOR GENES}

PTEN (also known as MMAC1) is a major new tumor suppressor gene located at human chromosome 10q23 (Steck et al 1997). It comprises 9 exons with a coding sequence of $1212 \mathrm{bp}$ and encodes a 403 amino acid phosphatase protein that shares sequence homology with the dual-specificity phosphatase family ( $\mathrm{Li}$ and Sun 1997). PTEN is a tumor suppressor gene based on the presence of inactivating mutations in human brain, breast, and prostate cancers (Li et al 1997; Steck et al 1997). Further studies extended initial observations in a variety of different tumor 
entities. Somatic mutations of this gene occur in several types of cancers, including gliomas and glioblastoma, as well as prostate, kidney and breast carcinomas (Fallani et al 1997; Daniel et al 1995; Steck et al 1997). Germline mutations of PTEN gene underlie Cowden disease, an autosomal dominant disorder associated with an increased risk for breast and thyroid cancer, and possibly also for endometrial malignancy (Liaw et al 1997). In addition, multiple oral papillomas are associated with Cowden's disease (Greer et al 1976).

LKB1 (also called STK11) is a tumor suppressor gene mapped to 19p13.3, and it encodes a serine/threonine kinase which is highly homologous $(84 \%)$ to Xenopus serine/threonine kinase XEEK1 ( $\mathrm{Su}$ et al 1996). Germline mutations in the LKB1 gene have been associated with Peutz-Jeghers syndrome (PJS) (Hemminki et al 1998; Jenne et al 1998), which is characterized by hamartomatous intestinal polyposis, mucocutaneous pigmentation, and increased risk for cancer of multiple organ systems (Phillips et al 1994). Somatic mutation in LKB1 is a rare event in most sporadic tumor types: melanoma, pancreatic, gastric, ovarian granulose, cervical, lung, soft tissue, renal tumors, colorectal, testicular, breast, gastric carcinoma, and colon cancer (Avizienyte et al 1998; Avizienyte et al 1999; Bignell et al 1998; Park et al 1998; Resta et al 1998). Thus far, reports on the mutation analysis of this gene in HNSCC are few.

\subsection{SQUAMOUS CELL CARCINOMA OF THE HEAD AND NECK}

Squamous cell carcinoma of the head and neck (HNSCC) is a group of malignant epithelial diseases arising from the mucosa of the upper aerodigestive tract including the lips, oral cavity, oropharynx, nasopharynx, hypopharynx, larynx, maxillary sinus, nasal cavity and ethmoid sinus, and salivary glands (Fig 3). This disease is characterized by local tumor aggressiveness, early recurrence, and high frequency of second primary tumors. HNSCC represents the eighth most prevalent malignancy worldwide, with nearly half a million new cases per year (Parkin et al 1999). According to the report by Finnish Cancer Registry in 2002, each year approximately 600 new cases of head and neck cancer are diagnosed in Finland, and the age-adjusted incidence rates is 10.7 per 100,000 in male and 3.8 
per 100,000 in female (Finnish Cancer Registry 2002). Treatment of head and neck cancers is based on surgery or radiotherapy, or their combination, or on chemoirradiation (Luukkaa et al 2003; Forastiere et al 2003).

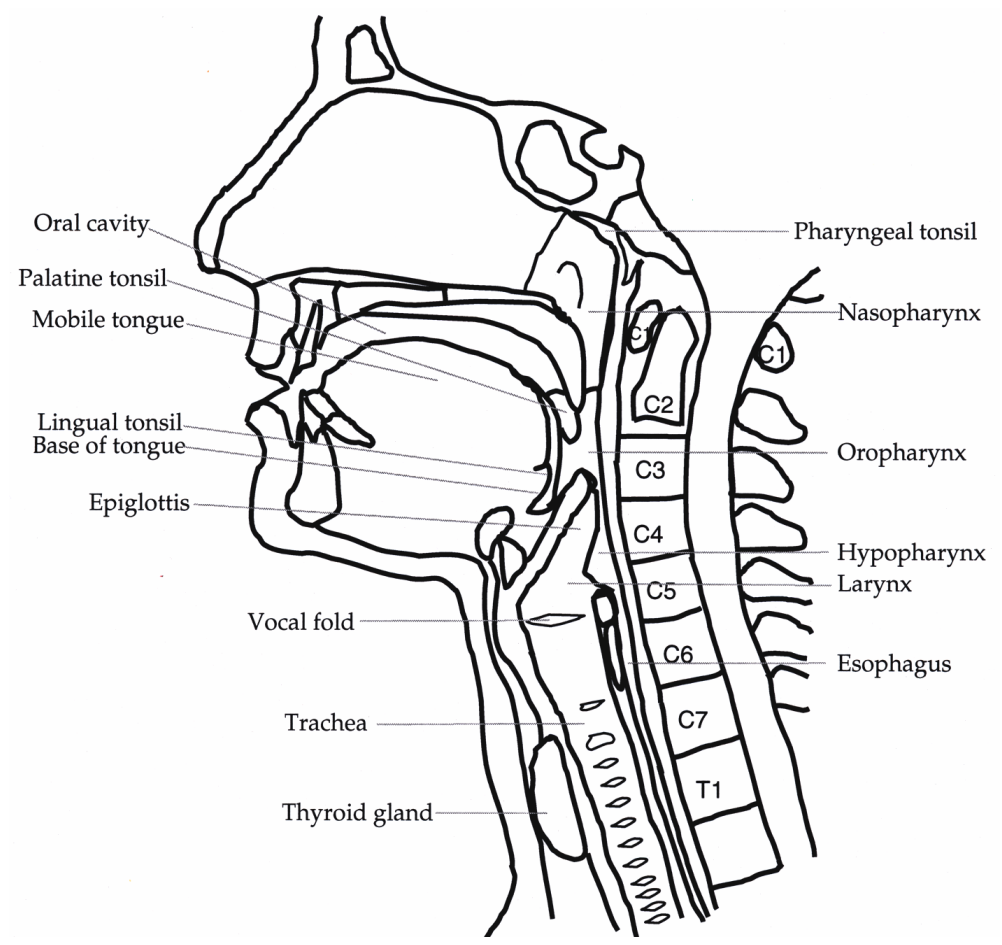

Figure 3. Anatomic overview of head and neck region, modified from (Netter 2001) in Plate 57.

\subsubsection{Etiology and risk factors for the head and neck cancer}

As many as 80 to $90 \%$ of all head and neck cancers except cancer of the salivary glands may be attributed to the known risk factors tobacco smoking and alcohol consumption (Decker and Goldstein 1982; Franceschi et al 1990; Spitz 1994; Licitra et al 2002), although a minority of head and neck cancer patients have no history of tobacco or alcohol use, suggesting other possible contributing exposures (Gillison et al 1999). Several oncogene activations (Ras, Myc, epidermal growth factor receptor, and cyclin D1) and tumor suppressor gene inactivations (p53, 
$p 16^{I N K 4 A}, R b$ ) have been identified in primary HNSCC, as reviewed in (Forastiere et al 2001; Mao et al 2004). The p53 gene is probably the most widely studied gene in HNSCC. The reported frequency of p53 mutations in HNSCC varies widely, from 30 to $70 \%$, and this may be a reflection of the techniques used to detect mutations, the regions of $p 53$ subjected to analysis, and differences in mutation rates between anatomical sites. Many studies analyzing gene sequence have focused on exon 5-8 of p53, since the majority of mutations occur here (Gasco and Crook 2003; Blons and Laurent-Puig 2003). The frequency of $p 53$ mutations in HNSCC seems to be correlated with the dose-dependant effect of tobacco and inversely associated with HPV infection, as reviewed in (Blons and Laurent-Puig 2003). The spectrum of chromosomal loss increased progressively at each histopathological step from benign hyperplasia to invasive cancer in HNSCC (Califano et al 1996). Viruses, mainly HPV and Epstein-Barr virus (EBV), have been noticed to be connected with head and neck cancer development. The association of infection with HPV and cancers of the oral cavity, larynx, and nasal and paranasal regions was originally reported in (Syrjänen et al 1982; Syrjänen et al 1983b; Syrjänen et al 1983a). The association of infection by EBV and nasopharyngeal carcinomas was first suggested by Old et al in 1960s, as reviewed in (zur Hausen 1999b).

\subsubsection{Tumor classification}

The International Union Against Cancer (UICC) TNM classification is identical to that of the American Joint Cancer Committee (AJC). The T categories are defined by tumor dimension, the $\mathrm{N}$ categories are according to whether the cancer has spread to the regional lymph nodes, and the $\mathrm{M}$ catogories indicate whether the cancer has any distant spreading metastasis (Table 2). Tumor stage is classified by adding the TNM data together (Table 3). 
Table 2. Tumor classification for oropharyngeal cancer (UICC 2002)

\begin{tabular}{|c|c|}
\hline TNM & Definition \\
\hline TX & primary tumor cannot be assessed \\
\hline T0 & no evidence of primary tumor \\
\hline Tis & carcinoma in situ \\
\hline $\mathrm{T} 1$ & tumor \# $2 \mathrm{~cm}$ \\
\hline $\mathrm{T} 2$ & tumor $>2 \mathrm{~cm}$ but \# $4 \mathrm{~cm}$ \\
\hline T3 & tumor $>4 \mathrm{~cm}$ \\
\hline $\mathrm{T} 4 \mathrm{a}$ & tumor invades any of the following: larynx, deep/extrinsic musle \\
\hline $\mathrm{T} 4 \mathrm{~b}$ & $\begin{array}{l}\text { of tongue, medial pterygoid, hard palate, or mandible } \\
\text { tumor invades any of the following: lateral pterygoid muscle, } \\
\text { pterygoid plates, lateral nasopharynx, skull base; or it encases the } \\
\text { carotid artery }\end{array}$ \\
\hline NX & regional lymph nodes cannot be assessed \\
\hline No & no regional lymph node metastasis \\
\hline N1 & metastasis in a single ipsilateral lymph node \#3 cm \\
\hline $\mathrm{N} 2 \mathrm{a}$ & metastasis in a single ipsilateral lymph node $>3 \mathrm{~cm}$ but $\# 6 \mathrm{~cm}$ \\
\hline $\mathrm{N} 2 \mathrm{~b}$ & metastasis in multiple ipsilateral lymph nodes \# $6 \mathrm{~cm}$ \\
\hline $\mathrm{N} 2 \mathrm{c}$ & metastasis in bilateral or contralateral lymph nodes, \# $6 \mathrm{~cm}$ \\
\hline N3 & metastasis in a lymph node $>6 \mathrm{~cm}$ \\
\hline $\mathrm{MX}$ & distant metastasis cannot be assessed \\
\hline M0 & no distant metastasis \\
\hline M1 & presence of distant metastases \\
\hline
\end{tabular}


Table 3. Tumor stage classification for oropharyngeal cancer (UICC 2002)

\begin{tabular}{cccc}
\hline TNM stage & T & N & M \\
\hline 0 & Tis & N0 & M0 \\
I & T1 & N0 & M0 \\
II & T2 & N0 & M0 \\
III & T1, T2 & N1 & M0 \\
III & T3 & N0, N1 & M0 \\
IVA & T1-T3 & N2 & M0 \\
IVA & T4a & N0-N2 & M0 \\
IVB & T4b & any N & M0 \\
IVB & any T & N3 & M0 \\
IVC & any T & any N & M1
\end{tabular}

\subsubsection{HPV in HNSCC}

To date, more than 1900 studies on the presence of HPV DNA in HNSCC have emerged. The frequency of HPV DNA in HNSCC has a large variation depending on tumor site, material and methods applied, as well as number of cases included, in average range from 9 to 60\% (Snijders et al 1996; Paz et al 1997; McKaig et al 1998; Gillison et al 2000; Mork et al 2001). Several case-control studies as well as a meta-analysis suggested that high-risk HPVs are associated with HNSCC (Miller and Johnstone 2001) (Table 4). In situ hybridization (ISH) reveals that HPV DNA is located in tumor cells but not in the surrounding stroma or the nondysplastic surface epithelium in HNSCC (Niedobitek et al 1990; Gillison et al 2000). Klussmann et al documented for the first time that viral loads as determined by quantitative real-time PCR in microdissected HPV-16 positive tonsillar tumors were higher than in whole-sample DNA preparations, indicating that HPV DNA is present in the tumor and not in the stroma or other cells (Klussmann et al 2001). By the more sensitive PCR assay, however, HPV DNA has also been detected in tumor-free resection margins of HPV-positive HNSCC (Snijders et al 1996; 
Badaracco et al 2000; Klussmann et al 2001). Approximately half the HPV DNApositive HNSCC expresses E6/E7 mRNA in the tumors (Wiest et al 2002; Balz et al 2003). HPV DNA-positive tumors with no E6/E7 mRNA expression possibly underwent a deletion within the E6 gene (Wiest et al 2002). Interestingly, E6/E7 mRNA expression occurs mostly in tumors with wild-type $p 53$, reduced $\mathrm{pRb}$, and overexpressed p16, whereas tumors without E6/E7 expression are associated with mutant p53, normal pRb, and low levels of p16 (Wiest et al 2002). HPV-16 E6 transcript expression is correlated with basaloid morphology (van Houten et al 2001). A rather frequent coexistence of HPV DNA and p53 mutations was found in HNSCC (Barten et al 1995; Chiba et al 1996; Scholes et al 1997), which is in contrast to the situation in cervical and other anogenital cancers, which show an almost complete inverse correlation between HPV and $p 53$ mutations and share a conspicuous basaloid morphology (zur Hausen 1996).

Table 4. High-risk HPVs in HNSCC (case-control studies)

\begin{tabular}{|c|c|c|c|c|c|}
\hline Reference & Tumor stie & Material & $\begin{array}{c}\text { No of case / } \\
\text { control }\end{array}$ & HPV\% & $\begin{array}{l}\text { Odds } \\
\text { ratio } \\
\end{array}$ \\
\hline $\begin{array}{c}\text { Schwartz et al } \\
1998\end{array}$ & Oral cavity & $\begin{array}{c}\text { Oral exfoliated } \\
\text { cells }\end{array}$ & 237 / 435 & $5.9 \% / 4.1 \%$ & 1.3 \\
\hline $\begin{array}{c}\text { Nishioka et al } \\
1999\end{array}$ & head and neck & $\begin{array}{l}\text { Fresh-frozen } \\
\text { tissue }\end{array}$ & $74 / 70$ & $16.2 \% / 4.2 \%$ & 4.3 \\
\hline $\begin{array}{l}\text { Strome et al } \\
2002\end{array}$ & Tonsil & $\begin{array}{l}\text { Paraffin- } \\
\text { embedded } \\
\text { tissue }\end{array}$ & $52 / 48$ & $40.1 \%$ / 6.3\% & $\mathrm{NA}^{*}$ \\
\hline \multirow{2}{*}{ Chen et al 2002} & \multirow{2}{*}{ Oral cavity } & \multirow{2}{*}{$\begin{array}{c}\text { Paraffin- } \\
\text { embedded tissue }\end{array}$} & \multirow{2}{*}{29 / 29} & $\begin{array}{c}85.7 \% / 32 \% \\
(\mathrm{HPV}-16)\end{array}$ & 12.8 \\
\hline & & & & $\begin{array}{c}71.4 \% / 11.5 \% \\
(H P V-18)\end{array}$ & 19.2 \\
\hline $\begin{array}{l}\text { Herrero et al } \\
2003\end{array}$ & $\begin{array}{c}\text { Oral cavity and } \\
\text { oropharynx }\end{array}$ & $\begin{array}{c}\text { Oral exfoliated } \\
\text { cells }\end{array}$ & $601 / 613$ & $5.3 \% / 6.9 \%$ & $\mathrm{NA}^{*}$ \\
\hline $\begin{array}{l}\text { Smith et al } \\
\quad 2004\end{array}$ & $\begin{array}{c}\text { Oral cavity and } \\
\text { oropharynx }\end{array}$ & $\begin{array}{l}\text { Oral exfoliated } \\
\text { cells }\end{array}$ & $201 / 333$ & $28.4 \% / 10.8 \%$ & 2.6 \\
\hline
\end{tabular}

*not available 


\subsubsection{HPV in SCC of tonsils}

HPV DNA is detected in 42 to $100 \%$ of all cases of tonsillar carcinoma, thus appearing more frequently than in other head and neck carcinomas (Snijders et al 1992; Steinberg and DiLorenzo 1996; Paz et al 1997; Andl et al 1998; Gillison et al 2000; Mellin et al 2000; Mork et al 2001; Mellin et al 2002; Syrjänen 2004; Li et al 2004). Tonsillar SCC often contains episomal HPV with or without the deletion of E2 sequence (Mellin et al 2002). HPV-positive tonsillar SCC has been suggested as a distinct biological group by several studies. For instance, HPV-16 is predominant; it has rather frequent oncogene E6/E7 expression with wild-type p53 (Wiest et al 2002; Balz et al 2003), reduced pRb and cyclin D1 expression and increased p16 expression (Andl et al 1998; Wilczynski et al 1998; Klussmann et al 2003; Li et al 2004). Patients with HPV-positive tonsillar SCC are younger in age, use less tobacco and alcohol, and have better prognosis than do patients with the HPV-negative cancers (Mellin et al 2000; Strome et al 2002; Li et al 2003). Epidemiological data showed that patients with HPV-associated anogenital cancers had a 4.3-fold increased risk for tonsillar SCC, whereas patients with HPV-unrelated cancer (cancers of colon, stomach and breast) had no increased risk for developing tonsillar SCC, suggesting that HPV may be a common etiological factor for the link between tonsillar and anogenital SCC (Frisch and Biggar 1999).

\subsubsection{HPV DNA in tumor-free tonsils}

The detection of HPV DNA in tumor-free tonsils has been reported in only a few studies (Smith et al 1993; Watanabe et al 1993; Fukushima et al 1994; Tominaga et al 1996; Strome et al 2002) and others failed to detect the viral DNA in tonsillitis samples (Brandsma and Abramson 1989; Niedobitek et al 1990; Snijders et al 1992; Klussmann et al 2001). The overall frequency of HPV DNA in normal tonsillar mucosa or benign lesions is $8.5 \%$ (17 of 200), consisting of 70\% with HPV-16 and $30 \%$ with HPV-6/11, as summarized in a recent review (Syrjänen 2004). The reason for the association of HPV with the tonsil remains unclear. HPV seems to 
be important, especially in tonsillar carcinogenesis, and data on HPV infection in tumor-free tonsils is based on small study populations.

Presence of the IgG antibody to the HPV-16 L1 capsid protein is an indication of persistent infection, and presence of an antibody against HPV-16 E6 or E7 may suggest the HPV-associated malignancy (Herrero et al 2003; Zumbach et al 2000). Seroepidemiological data showed a significantly increased risk for HNSCC is associated with HPV-16 seropositivity (Mork et al 2001). Serum antibodies against HPV-16 proteins have been detected amongh healthy individuals (Hamsikova et al 1998). The concomitant of presence of HPV DNA in tumor-free tonsillar tissue and seropositivity, however, has not been investigated as yet. 


\section{AIMS OF THE STUDY}

The etiology of HNSCC is considered to be multifactorial. Besides the well-known main risk factors, tobacco and alcohol, the presence of some DNA tumor viruses as well as the genetic alteration also play a role. An association between infection by HPV and HNSCC has been based mainly on the detection of HPV DNA in tumor samples and on the case-control studies. Little is known about the physical status of HPV in HNSCC, with no systematic study in infection by HPV in tumorfree tonsillar tissue. Thus far no in vitro model exists to study mechanisms of HPV in tonsillar carcinogenesis.

More specifically, the aims of this thesis were to study:

1. the role of somatic mutations of PTEN and $L K B 1$ genes in laryngeal tumors

2. the prevalence, viral load, and physical status of HPV DNA in HNSCC

3. the frequency of HPV DNA and seroprevalence in patients with tumor-free tonsils, and

4. to establish and characterize HPV-16 DNA immortalized HTE cell lines 


\section{PATIENTS, MATERIALS, AND METHODS}

\subsection{PATIENTS AND MATERIALS (I, II, III)}

All patients in Studies I, II, and III were from Helsinki University Central Hospital, Department of Otorhinolaryngology - Head and Neck Surgery (Table 5). Fresh tissue obtained from surgical operations and tonsillar exfoliated cells collected with Cytobrush Plus Cell Collector (Medscand Medical AB, Sweden) into PBS were immediately stored at $-70^{\circ} \mathrm{C}$ till analysis.

Table 5. Patients and clinical samples

\begin{tabular}{|c|c|c|c|c|c|}
\hline & \multicolumn{2}{|c|}{ Patients' diagnosis (number of cases) } & $\begin{array}{c}\text { Specimens for } \\
\text { HPV-PCR }\end{array}$ & Luminex & IHC/ISH $^{*}$ \\
\hline $\begin{array}{l}\text { Study } \\
\text { I }\end{array}$ & \multicolumn{2}{|c|}{$\begin{array}{l}\text { Laryngeal carcinoma }(n=13) \\
\text { Laryngeal papilloma }(n=3) \text {, one with } \\
\text { malignant transformation }\end{array}$} & \multirow[b]{2}{*}{$\begin{array}{l}\text { Fresh-frozen tissue } \\
\text { containing at least } \\
40 \% \text { neoplastic cells }\end{array}$} & & \\
\hline $\begin{array}{l}\text { Study } \\
\text { II }\end{array}$ & Carcinomas of & $\begin{array}{l}\text { hypopharynx }(\mathrm{n}=10) \\
\text { larynx }(\mathrm{n}=18) \\
\text { mobile tongue }(\mathrm{n}=6) \\
\text { base of tongue }(\mathrm{n}=9) \\
\text { oral cavity }(\mathrm{n}=13) \\
\text { tonsil }(\mathrm{n}=5)\end{array}$ & & & \multirow{3}{*}{$\begin{array}{l}\text { Formalin- } \\
\text { fixed and } \\
\text { paraffin- } \\
\text { embedded } \\
\text { tissue }\end{array}$} \\
\hline \multirow{2}{*}{$\begin{array}{c}\text { Study } \\
\text { III }\end{array}$} & \multicolumn{2}{|c|}{$\begin{array}{l}\text { Tonsillitis }(\mathrm{n}=135) \\
\text { Tonsillar hypertrophy }(\mathrm{n}=77)\end{array}$} & $\begin{array}{l}\text { Fresh-frozen tissue } \\
\text { containing at least } \\
30 \% \text { epithelial cells }\end{array}$ & \multirow[t]{2}{*}{ Serum } & \\
\hline & \multicolumn{2}{|c|}{ Normal tonsil $(\mathrm{n}=189)$} & $\begin{array}{l}\text { Cytobrushed } \\
\text { exfoliated cells }\end{array}$ & & \\
\hline
\end{tabular}

* immunohistochemisty / in situ hybridization

\subsection{CELL LINES (IV)}

Primary human tonsillar epithelial (HTE) cells were derived from children's bilateral tonsillectomies. In these tonsils, HPV-PCR analysis showed no preexisting infection with HPV. HTE-114/K1, HTE-114/K2, HTE-114/K3, and HTE114/B have derived from HPV-16 immortalized primary HTE cells. The HPV-16 positive cervical carcinoma cell line $\mathrm{SiHa}$ and spontaneously transformed $\mathrm{HaCaT}$ human keratinocyte cell line were obtained from the American Type Culture Collection (ATCC). 


\subsection{PLASMIDS (IV)}

The plasmids, pHPV16 114/K and pHPV16 114/B, containing full-length HPV-16 DNA, were the kind gift of Dr. Matthias Dürst, University of Jena, Germany.

\subsection{METHODS}

Method

DNA extraction from patients' samples

Mutation analysis of PTEN and LKB1 genes

Detection and genotype of HPV DNA by PCR

Determination of HPV-16 viral load and physical status

Conventional cell culture

Transfection of cells

Raft culture

Anchorage-independent growth in soft agarose

Tumorigenicity assay

Electron microscopy examination

Cytogenetic analysis

Fluorescence in situ hybridization (FISH)

Southern blot hybridization

Northern blot hybridization

Immunohistochemistry (IHC)

Statistical analysis
Described in

I, II, III

I

I, III

III

IV

IV

IV

IV

IV

IV

IV

IV

IV

IV

II, IV

II, III

In situ hybridization (ISH)

Five- $\mu \mathrm{m}$ sections of formalin-fixed and paraffin-embedded tonsillar SCC tissue were deparaffinized and rehydrated. In situ hybridization was performed using the Ventana Discovery automated ISH-IHC Slide Stainer (Ventana Medical Systems, Inc., Tucson, AZ, USA). The sections were digested with protease 2 (Ventana) for $4 \mathrm{~min}$ before hybridization at $57^{\circ} \mathrm{C}$ for 14 hours with a Digoxigeninlabeled full-length HPV-16 DNA probe in ribohybe ${ }^{\mathrm{TM}}$ (Ventana) and followed with low- and high-stringent wash. The hybrids were detected with the BlueMap Detection Kit (Ventana) and counterstained with nuclear Fast Red (Ventana). After dehydration, the slides were mounted with Eukitt mounting medium (O. Kindler GmbH \& Co., Freiburg, Germany). The positive signals appeared in blue. 


\section{RESULTS AND DISCUSSION}

\subsection{SOMATIC MUTATION IN PTEN AND LKB1 GENES IS A RARE EVENT IN LARYNGEAL TUMORS (I)}

To determine whether PTEN and LKB1 tumor suppressor genes are mutated in laryngeal tumors, we screened 16 laryngeal tumor samples by genomic sequencing and SSCP assay. When we performed direct sequencing of the amplicon for PTEN mutations analysis, no mutations were evident in the coding sequences and exon/intron boundaries; to screen for LKB1 mutations, the SSCP assay was applied after PCR amplification of the nine exons of $L K B 1$. Differences in mobility pattern in the SSCP assay are usually suggestive of a variant, the nature of which should be examined by sequencing. In our hands, SSCP analysis of $L K B 1$ always revealed known mutations, and it is reasonable to assume the 70 to $80 \%$ sensitivity that is commonly reported for the method (Jordanova et al 1997). Our SSCP protocol was specifically optimized for the LKB1 gene analysis. To validate the SSCP results, exon 1 was directly sequenced from each sample with no mutations observed in exon 1 and the respective exon/intron boundaries. The methods we used to detect mutations would not have detected some mutation types, such as large genomic deletions or alterations in the promoter region.

Several tumor suppressor genes have been demonstrated to play an important role in human tumors, including head and neck cancers. Our results are in agreement with reports showing that in HNSCC, somatic mutations in PTEN gene are infrequent (Henderson et al 1998; Gasparotto et al 1999; Hu et al 1999; Chen et al 2000; Mavros et al 2002). Other studies, however, imply that mutation of PTEN might play a role in the genesis of some HNSCC, ie., carcinomas of the oropharynx, larynx, and hypophaynx (Okami et al 1998; Shao et al 1998; Poetsch et al 2002). Analysis of PTEN expression at protein level is probably more relevant for the elucidation of its role in head and neck tumors. In laryngeal papillomas, PTEN protein is consistently overexpressed (Zhang and Steinberg 2000). Levels of 
PTEN protein vary from negative to highly expressed in SCC of the tongue and oral cavity, and loss of PTEN expression is significantly associated with poorer prognosis (Lee et al 2001; Squarize et al 2002). The rate of PTEN inactivation at protein level may be more frequent than that identified at the genomic level in HNSCC, and the inactivation of PTEN by either genetic alteration or by the loss of a PTEN transcript may play a role in the pathogenesis of some oral cancer (Shin et al 2002).

\subsection{PREVALENCE AND PHYSICAL STATUS OF HPV IN HNSCC (II)}

8.2.1. Prevalence, genotype, viral load, and physical status of HPV DNA in HNSCC

By SPF10 PCR screening and INNO-LiPA HPV genotyping assay, we found that $61 \%$ (37 of 61 ) of the tumors of HNSCC patients harbored HPV DNA. The most frequently detected type was HPV-16, followed by HPV-33 (Table 6). None of our samples were positive for the cutaneous HPVs. Our findings support the role of high-risk types of HPV, especially HPV-16, in head and neck carcinogenesis. In line with other reports (Snijders et al 1992; Paz et al 1997; Mellin et al 2000; Klussmann et al 2001), we also observed a high prevalence of high-risk HPV-DNA in tonsillar carcinoma $(n=5,100 \%)$. We were able to demonstrate by ISH that HPV-16 DNA was localized only in tumor cells of a tonsillar SCC (Fig 4).

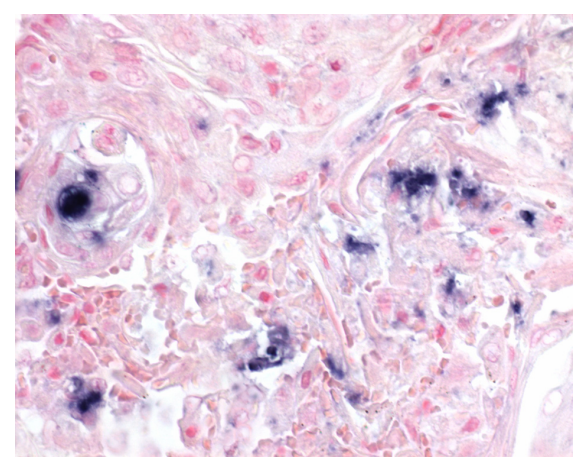

Figure 4. Photomicrograph shows that HPV-16 DNA (in blue) located in poorly differentiated dysplastic epithelial cells in tonsillar SCC. Magnification $\times 400$. 
Table 6. Frequency and genotypes of HPV DNA in 61 HNSCC patients

\begin{tabular}{lccccccc}
\hline Site of tumor (n) & HPV-16 & HPV-33 & $\begin{array}{c}\text { HPV- } \\
6 / 16\end{array}$ & $\begin{array}{c}\text { HPV- } \\
16 / 33\end{array}$ & $\begin{array}{c}\text { HPV- } \\
6 / 11 / 16 / 51 / 52\end{array}$ & Unknown & Total \\
\hline Hypopharynx (10) & 2 & 1 & 1 & 1 & 0 & 0 & HPV-DNA(\%) \\
Larynx (18) & 5 & 0 & 1 & 2 & 1 & 0 & $9(50)$ \\
Base of tongue (9) & 2 & 4 & 0 & 1 & 0 & 0 & $7(8)$ \\
Mobile tongue (6) & 3 & 0 & 0 & 1 & 0 & 0 & $4(7)$ \\
Oral cavity (13) & 6 & 0 & 0 & 0 & 0 & 1 & $7(54)$ \\
Tonsil (5) & 5 & 0 & 0 & 0 & 0 & 0 & $5(100)$ \\
\hline Total (61) & 23 & 5 & 2 & 5 & 1 & 1 & $37(61)$
\end{tabular}

Viral load of HPV-16 DNA in HNSCC was analyzed by real-time PCR. Even considering that some differences existed in the proportion of carcinoma cells (40 to $100 \%$ ) and in the amount of material used for DNA extraction, large variation appeared in the viral load between tonsillar SCC and non-tonsillar HNSCC. The median viral load in tonsillar specimens was thus approximately 80,000 times as high as in non-tonsillar HNSCC specimens (Fig 2, Study II). Furthermore, the median viral load in tonsillar SCC that harbored episomal viral DNA was 11.6 times that in the integrated group. This high viral load of HPV-16 DNA in tonsillar carcinomas has also been observed by others (Table 7). High viral load in tonsillar SCC favors detection of HPV, and this might explain the high prevalence of HPV-DNA in tonsillar SCC samples. It is unclear why the viral load in tonsillar carcinomas is markedly higher than at other sites of HNSCC.

Table 7. Viral load in HNSCC

\begin{tabular}{l|l}
\hline Site of tumor & HPV-16 DNA (copies/genome) \\
\hline \multirow{2}{*}{ Tonsillar SCC } & $2.3-245$ (Table II, study II) \\
& $10-15,400$ (Mellin et al 2002) \\
& $6.6 \times 10^{-4}-172$ (Klussmann et al 2001) \\
\hline HNSCC (mainly oropharyngeal SCC) & $1.8 \times 10^{-2}-322$ (Ha et al 2002) \\
\hline Non-tonsillar HNSCC & $5 \times 10^{-5}-3.4 \times 10^{-2}$ (II) \\
\hline
\end{tabular}


Viral DNA integration often leads to the disruption of E1/E2 genes in HPVassociated cervical lesions (Kalantari et al 1998). In our study, determination of viral physical status was based on the assumption that the E2 gene is disrupted in integrated viral DNA. Thus, episomal viral DNA has equivalent copy numbers of the E2 and the E6 genes, and mixed forms have smaller copy numbers of the E2 than of the E6 (Peitsaro et al 2002). We observed that HPV-16 DNA existed in all three forms: only episomal $(n=8)$, only integrated $(n=11)$, and mixed $(n=4)$. The disrupted E2 gene is quite common in our study: 15 of $25(60 \%)$. The minor disadvantages of our assay for determination of viral physical status stem from the assumptions that viral integration occurs within the selected site of the E2 gene and no mutations exist at sites of PCR primers of E2 region. Although disruption of the E2 gene has been considered as consequence of viral integration, episomal viral DNA with no detectable E2 DNA also occurs in tonsillar SCC (Mellin et al 2002).

\subsubsection{Absence of viral capsid protein expression in HNSCC}

Despite the high copy numbers of episomal HPV-16 DNA in tonsillar carcinomas, HPV L1 capsid protein was surprisingly undetectable by immunohistochemistry in any of the $36 \mathrm{HPV}$-positive tissue sections, whereas it was expressed strongly in control samples from a cervical intra-epithelial neoplasia type III and in a juvenile-onset laryngeal papilloma. Thus, undetectable HPV L1 protein in our tonsillar SCC samples was not due to technical reasons. It would, however, be of interest to look at L1 mRNA expression in the HPV-containing tonsillar SCC samples. In tonsillar carcinoma, HPV was reported to be correlated with a poor differentiation, no terminal differentiation, and basaloid histological appearance (Klussmann et al 2001; Wilczynski et al 1998). Our observation supports the view that the expression of viral capsid proteins requires terminal differentiation of host cells. 


\subsubsection{Correlation of HPV DNA status and clinical outcome}

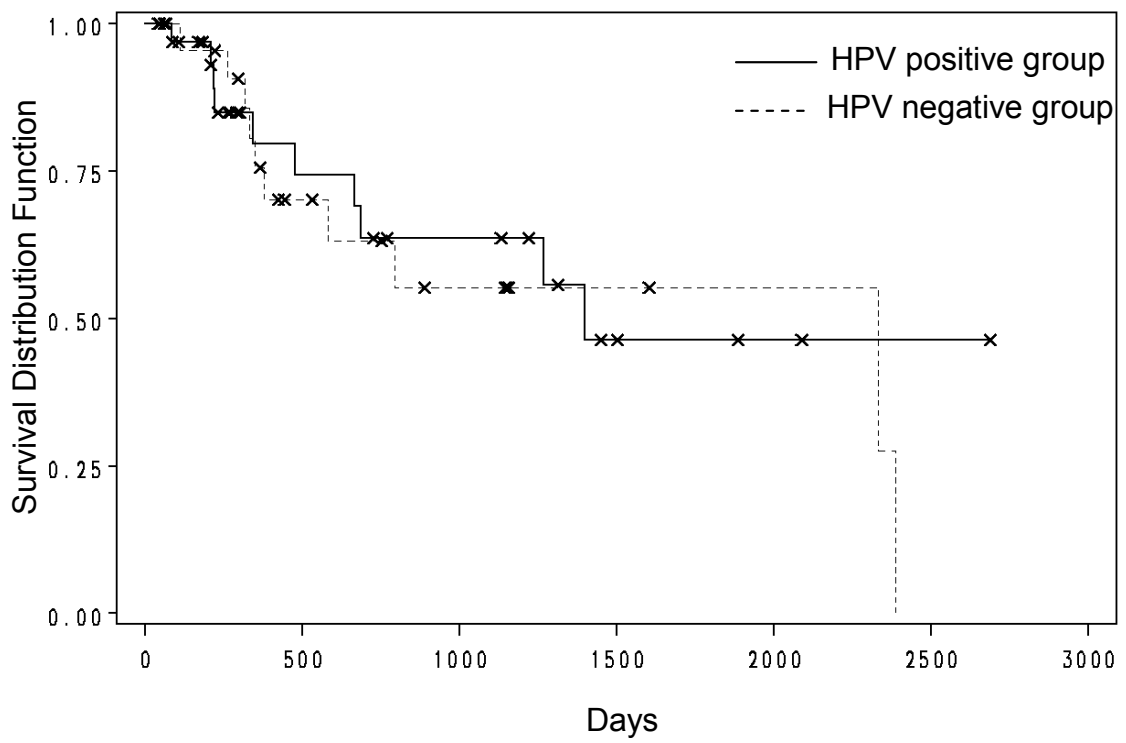

Figure 5. Kaplan-Meier survival graph showing that patients harbouring HPVpositive HNSCC had a similar survival profile as the HPV-negative patients. Fifty-nine HNSCC patients were included in the analysis.

By Kaplan-Meier survival analysis, we observed that HPV-positive patients had similar survival profile as the HPV-negative ones (Fig 5). Viral load had no statistically significant effect on the survival among those patients with HPV-16 positive HNSCC specimens (data not shown). Interestingly, we found that large tumors (T3 and T4) were significantly over-represented among the samples harboring episomal HPV-16 DNA, as compared to those which contained integrated or mixed forms of the viral DNA (Fig 3, Study II). However, the number of patients was rather small, and follow-up time quite short. Reports on the impact of HPV-positivity on prognosis in HNSCC have been controversial. Some studies reported that the prognosis of patients is not correlated with the detection of HPV DNA or with the viral physical status (Pintos et al 1999; Badaracco et al 2000). Others, however, observed that patients with HPV-positive HNSCC had a better overall and disease-specific survival than did the HPVnegative group (Ringstrom et al 2002). This correlation has also been observed 
among tonsillar carcinoma patients, plus the fact that higher viral load correlated with better clinical outcome in tonsillar SCC harboring episomal HPV-16 (Mellin et al 2002). The number of cases in those studies was relatively small (11 to 101). Thus, large study populations and a long follow-up time are required for clarificaton of this issue.

\subsection{PRESENCE OF HPV-16 DNA BUT NO OTHER TYPES IN TUMOR- FREE TONSILS (III)}

\subsubsection{Presence of HPV DNA and HPV genotypes in tumor-free tonsils}

We analyzed HPV DNA in tumor-free tonsillar tissue by nested PCR using the consensus primers My09/11 and GP5+/6+; the overall prevalence of HPV-16 DNA in tonsillar tissue was $6.1 \%$ (13 of 212) in patients operated on for tonsillitis or tonsillar hypertrophy, and no other type of HPV was detectable (Table 1a, Study III). No significant difference was observed between the positivity of HPV DNA in patients with tonsillitis (7.\%, 10 of 135) and tonsillar hypertrophy (3.9\%, 3 of 77). In contrast, only one tonsillar exfoliated cell sample from 189 control subjects with normal tonsils had detectable HPV DNA, and this one was typed as HPV-58. Thus, the presence of HPV-DNA in tonsillar tissue was significantly higher ( $\mathrm{p}<0.05$, Fisher's exact test, two-tailed) than that in tonsillar exfoliated cells. The frequency of HPV DNA in normal tonsils or tonsillitis was summarized in a recent review that out of 200 samples from 10 original studies, 6\% (12 of 200) were positive for HPV-16 and 2.5\% (5 of 200) were positive for HPV-6/11, thus, the overall frequency of HPV DNA was 8.5\% (17 of 200) (Syrjänen 2004).

Since in our study the samples from patients and control subjects were not obtained in the same way, we were not able to determine the concordance of HPV-DNA positivity in tonsillar tissue and that in tonsillar exfoliated cells. Data on this are controversial. One study showed a lower prevalence of HPV DNA in oral exfoliated cells, scraped superficially with soft toothbrushes, than that in oral biopsies among HNSCC patients (Herrero et al 2003). These authors suggested that the HPV status in exfoliated cells did not accurately reflect that in the tumor; however, other study observed that $57.9 \%$ of the patients $(n=190)$ with cancer of 
oral cavity or oropharynx were positive for HPV in both tumor tissue and oral exfoliated cells, collected by oral rinse, indicating good correlation of HPV-DNA positivity from tumor tissue and that from oral exfoliated cells (Smith et al 2004). Reliability of the exfoliated cells for analysis of HPV DNA by PCR needs to be evaluated further regarding the sampling methods, tumor or tumor-free samples, and specific anatomic sites of the head and neck.

Interestingly, in our study viral DNA prevalence was highest in preschool children aged between 1.5 and 6 years (11.5\%, 3 of 26) among all age groups. It is unknown how these children originally acquired the HPV-16 DNA in their tonsils. Vertical transmission of HPV from mothers to their children, or additional sources such as breast milk, siblings via kissing, or exposure to contaminated fomites is feasible, as suggested in one review (Syrjänen and Puranen 2000). In our study population, no patients older than 33 years was positive for HPV DNA in their tonsils, allowing speculation that, if these patients did not develop precancer or cancer lesions, HPV-16 DNA had been cleared by their immune system. Infection by HPV is common, but it rarely develops into cancer (Bauer et al 1991).

\subsubsection{Seroprevalence of antibodies against HPV-16 L1, E6, and E7}

The overall seroprevalence of HPV-16 L1 was 11.8\% (25 of 212) in patients group and $8.5 \%$ (16 of 189) in control subjects (Table 1, Study III). The highest seroprevalence appeared in the group aged between 26 and 40 years in both patients and control subjects, but not significantly. It is unknown whether these patients and control subjects had had HPV infection at sites other than their tonsils, since the HPV-16 L1 antibody can persist for many years and is a marker for persistant infection by HPV-16 (Shah et al 1997; af Geijersstam et al 1998), and in females is associated with lifetime number of sexual partners (Dillner et al 1996). Although serum antibodies against HPV-16 E6 and E7 proteins were detectable in our patients and control subjects, prevalences were low (0 to $2.8 \%$ ) (Table 1, Study III). Detection of serum antibodies against HPV-16 E6 and E7 proteins among all age healthy individuals has been observed by several studies (Muller et al 1995; Mund et al 1997; Hamsikova et al 1998). Antibody responses to 
HPV-16 E6 and E7 fusion proteins are intriguing, because these E6 and E7 genes are involved in HPV-mediated cellular transformation, and such antibodies are markers for HPV-16 associated oropharyngeal cancer (Zumbach et al 2000; Herrero et al 2003).

\subsubsection{Non-concordance between presence of HPV DNA in tonsillar tissue and seropositivity to HPV proteins}

Double positivity of HPV-16 DNA in tonsillar tissue and serum antibodies against any HPV-16 proteins was apparent in 2 of 212 patients; both were male young adults and had elevated serum antibodies against HPV-16 L1 proteints (all coefficients $<0.10$, all $\mathrm{p}>0.4$, Spearman correlation coefficients). No concordance thus exists between the presence of HPV-16 DNA in tumor-free tonsillar tissue and seropositivity against HPV-proteins. Our patients' HPV-16 DNA was detected at only one visit, and we lack knowledge of how long the HPV DNA had been in their tonsillar tissue and whether it was a transient infection. A single detection of viral DNA is less likely to lead to seroconvertion than is the case for patients in whom HPV-16 DNA is detectable at several visits (Carter et al 2000; Carter et al 1995; Carter et al 1996; de Gruijl et al 1997). Most HPV-16 seroconversions were detected 6 to 12 months after detection of HPV-16 DNA, and transient HPV-DNA is associated with a failure to seroconvert following incident HPV infection (Carter et al 2000). Conversely, those seropositive patients with no detectable HPV DNA in their tonsils may harbor the viral DNA at other anatomic sites than one of their tonsils.

\subsection{ESTABLISHMENT AND CHARACTERIZATION OF HPV-16 DNA IMMORTALIZED HUMAN TONSILLAR EPITHELIAL CELL LINES (IV)}

8.4.1. Growth and differentiation of HPV-16 DNA transfected human tonsillar epithelial cells

The introduction of full-length HPV-16 plasmid with its own promotors, 114/K or 114/B, into primary human tonsillar epithelial (HTE) cells from two donors, respectively, resulted in cell infinite growth. The immortalization properties of 
HPV-16 have been mapped to oncogenes E6 and E7 (Hawley-Nelson et al 1989; Liu et al 1999). Subculturing HPV-transfected HTE cells on plastic dishes revealed no significant changes in cellular morphology. In vitro, the differentiated phenotype of epithelial cells can be induced by growing cells at the air-liquid interface on collagenous substrata. If HPV-immortalized cells represent the tissue culture counterpart to naturally occurring premalignant cells, they should share many characteristics of dysplastic cells (Blanton et al 1991). We therefore used a raft culture system, which reproduces in vitro the differentiation patterns of epithelial cells in vivo, to search for the differences between normal and HPVtransfected HTE cells. We observed that the appearance of the HPV-16 transfected HTE cells in raft culture varied considerably in size and shape from the primary HTE cells. They showed disturbed cellular polarity, vacuolated cytoplasm, and an increased nucleus-to-cytoplasm ratio which resembled epithelial dysplasia in vivo. A weak-to intermediate expression level of cytokeratins (determined with pan cytokeratins 1, 5, 10, and 14) was detected in the HPV-transfected cells in rafts (Fig 2, Study IV). The poor differentiation of HPV-transformed cells was possibly a result of the expression of viral oncogenes E6 and E7 which stimulate cell proliferation in raft culture and leads to the formation of disorganized epithelial layers (Halbert et al 1992). By electron microscopy, we observed that HPV-16 transfected HTE cell lines presented numerous desmosomes and microvilli, characteristic components of epithelial cells.

\subsubsection{Tumorigenicity of HPV-16 transformed cell lines}

All HPV-transformed HTE cells failed to form colonies in soft agarose and tumors in nude mice, suggesting that HPV-transformed cells are non-malignant. The presence of HPV alone does not necessarily result in malignancy. Other co-factors may be necessary for full oncogenic expression, of which fibroblasts are perhaps one of the most important (Zheng and Vaheri 1995; Atula et al 1997; Olumi et al 1999). We also observed that a co-culture of HES fibroblasts with HPVtransformed HTE cells in soft agarose resulted in colony formation (Fig 6). Several growth factors are known to modulate cascades of signaling pathways in 
epithelial cell lines. Dysregulation of such cascades may lead to cell transformation and tumorigenesis (Ridley et al 1995; Dhawan et al 1999; LaRochelle et al 1999). For example, upregulation of keratinocyte growth factor (KGF) receptor in HPV-immortalized cells may subsequently result in KGFinduced anchorage-independent growth of the cells (Zheng et al 1995). KGF is a member of the fibroblast growth factor family and has unique target-cell specificity restricted to the epithelial cell type (Finch et al 1989; Aaronson et al 1991).
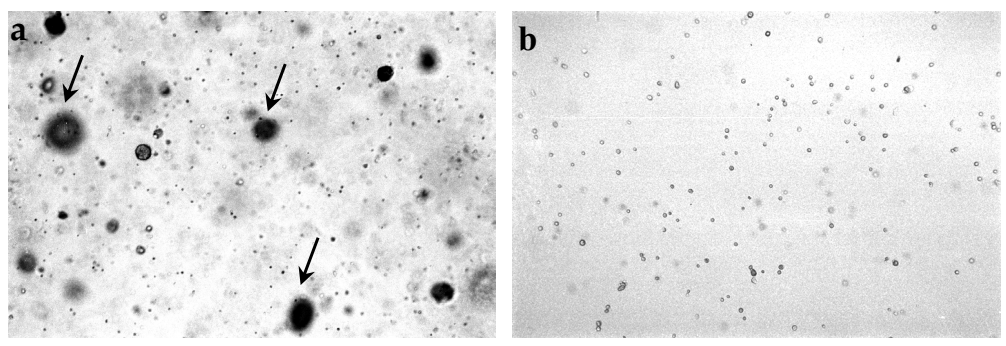

Figure 6. HES fibroblasts induced anchorage-independent growth of HPVtransformed HTE cells in soft agarose. a. Co-culture of HPV-transformed HTE cells and HES fibroblasts formed large colonies (arrow) in soft agarose. b. Culture of only HPV-transformed cells in soft agarose formed no colony.

\subsubsection{Cytogenetic aberration}

Unbanded metaphase spreads from all HPV-16 transfected HTE cell lines showed chromosome abnormalities such as chromosomal breakage, chromatid elongation (premature chromosome condensation), dicentric and acentric chromosomes, and numerical chromosomal changes $(\mathrm{n}=80$ - 100) (Fig 4, Study IV). Our observations are in line with that by others (Dürst et al 1987a; Hukku et al 2000). Mechanisms underlying HPV integration and chromosomal instability need to be further studied. 


\subsubsection{Physical status and chromosomal localization of viral DNA in HPV-16 transformed HTE cell lines}

Southern blot analysis indicated that all four HPV-transformed HTE cell lines harbored only integrated HPV-16 DNA (Fig 5, Study IV). We used real-time PCR with primers (Table 1, Study II) specific for the HPV-16 E2 and E6 regions to quantitate the copy numbers of the E2 and E6 DNA and found that each cell line contained equal amounts of E2 and E6 DNA copies, suggesting that integration did not occur within the selected E2 region. Although the E2 gene is often disrupted upon viral DNA integration in vivo (Kalantari et al 1998), integration sites do not necessary occur within the E2 gene in vitro transfection. The viral DNA integrated exclusively at chromosomal 7q31 in three cell lines originating from the same transfectant (HTE-114/K); and in a polyclonal cell line from another transfectant of a different donor (HTE-114/B), the viral DNA integrated at single locus near the telomere of the long arm of chromosome 9 (Fig 6, study IV). According to previous reports viral DNA integration sites seem to be random: Kahn and colleagues reported a tonsillar carcinoma case with HPV-6a integration at chromosomal 10q24 in tumor cells (Kahn et al 1994). In cervical carcinomas, integration of HPV has been mapped in many chromosomes, i.e., chromosomes 1 , $2,3,6,8,10,13,14,16,17,18,20$, and 22, with the integration event occurring at a single locus in each case (Dürst et al 1987b; Wilke et al 1996; Reuter et al 1998; Koopman et al 1999; Thorland et al 2000; Luft et al 2001). However, multi-site integration has also been evident in a cell line derived from oral carcinoma containing six viral integrated loci within chromosomal region 15q14-15 and five unidentifiable chromosomes (Steenbergen et al 1995). Several studies have reported no specific preferred chromosomal sites for viral DNA integration in HPV-immortalized cell lines (Weijerman et al 1997; Dürst et al 1995; Smith et al 1992; Popescu and DiPaolo 1990). In those studies, the authors also observed that viral DNA integrated in either a single locus or multi-site in chromosomes. It is unclear whether host-cell origin, HPV variants, transfection condition, or any combination of these may favor specific loci for viral integration. 


\subsubsection{Viral gene expression in HPV-16 transformed HTE cell lines}

The viral DNA was transcriptionally active in all transfected cells. Two major transcripts of 1.7 and $3.7 \mathrm{~kb}$ and one minor transcript of $2.4 \mathrm{~kb}$ existed in all four immortalized cell lines by northern blot hybridization with a full-length HPV-16 DNA probe as well as with an E7 specific probe (Fig 7, Study IV). In contrast, no viral transcript was detectable when the filter was hybridized with a fragment corresponding to the $\mathrm{L} 1$ region. We failed to demonstrate viral particles in the raft culture, which can be explained by the fact that these cells contained no episomal viral DNA. Viral particles have been identified in raft cultured cells derived from a cervical intraepithelial neoplasia type I lesion and HPV-immortalized keratinocytes containing episomal viral DNA (Meyers et al 1992; Frattini et al 1996). When a constructed chimeric HPV-18/16 plasmid DNA was introduced into primary keratinocytes and maintained episomally, the viral late functions (capsid gene expression and synthesis of virion) were active in raft cultures (Meyers et al 2002).

Our HPV-immortalized HTE cells are non-malignant and thus provide a useful in vitro model for studying further the multistep molecular events of HPV16 associated tonsillar carcinogenesis, as well as the effect of anti-virus and antitumor compounds. 


\section{CONCLUDING REMARKS}

The studies presented in this thesis have shown the following:

- Although mutations in many tumor suppressor genes play a role in head and neck carcinogenesis, our study suggests that PTEN and LKB1 are not among them in laryngeal tumors.

- Infection by high-risk types of HPV plays a role in the development of head and neck cancers, particularly in tonsillar carcinogenesis. HPV-16 DNA existed in episomal, integrated, and mixed forms in HNSCC. Tonsillar SCC harbored a remarkably higher viral load than did the others in HNSCC. Patients with HPV-positive tumors had a prognosis similar to those with HPVnegative ones.

- Only HPV-16 DNA, but no other types, presented in tumor-free tonsillar tissue. Detection of HPV-16 DNA in tonsillar tissue did not correlate with seropositivity against HPV proteins. HPV DNA is seldom detected in the exfoliated tonsillar cells in normal tonsils, suggesting that tonsillar crypt epithelial cells may be a reservoir for HPV-16 or normal tonsils seldom harbor HPV.

- Primary human tonsillar epithelial cells can be immortalized by introduction of full-length HPV-16 DNA which provides an in vitro model to study further multistep molecular events of HPV-16 associated tonsillar carcinogenesis, as well as treatment for the HPV-associated tonsillar carcinomas. 


\section{PERSPECTIVES}

Detection of HPV DNA in tumor or precancer samples does not on its own indicate that the virus plays a causal role in tumor development. Additional molecular data argue, however, that the virus may play such a role in a subset of HNSCC. Understanding the fundamental molecular changes of HNSCC may lead to improvements in therapy for patients with this disease.

Studies on the molecular mechanisms underlying HPV-associated head and neck carcinogenesis is hindered, because the HPV is not easy to propagate in vitro. We have established and characterized HPV-immortalized human tonsillar epithelial cell lines which allow us to further study multistep in molecular events (co-factors) in HPV-16 associated tonsillar carcinogenesis. In addition, these cell lines may provide an in vitro model to test effects of anti-viral and anti-tumor agents, as well as to study the response to radiotherapy. 


\section{ACKNOWLEDGEMENTS}

This thesis work has been carried out in the Department of Virology, Haartman Institute, University of Helsinki. I wish to express my gratitude to the former and current heads of the department, Professors Antti Vaheri, Carl-Henrik von Bonsdorff, and Klaus Hedman, for creating such a friendly atmosphere in the department and providing excellent working facilities.

No words can express my deepest gratitude to my supervisor, Professor Antti Vaheri, for his friendly and positive attitude and responsibility towards my work, his profound and wide knowledge in science, and his wise flexibility in conducting my research that made this thesis possible.

I warmly thank my co-supervisor, Dr. Leena-Maija Aaltonen, for introducing me to the complex world of head and neck cancers, her supervising and organizing the project, and even generously and graciously entertaining me in her own home.

I thank Professors Stina Syrjänen and Reidar Grenman for examining the manuscript of this thesis and their valuable suggestions on how to improve it.

Professor Pekka Karma, Acting Professor Jukka Ylikoski, and Docent Hans Ramsay are thanked for their positive attitudes towards research and providing working facilities in Department of Otorhinolaryngology - Head and Neck Surgery.

Docent Eeva Auvinen is sincerely thanked for her interest and scientific discussion about my work, for her unselfish help and encouragement during these years.

My gratitude goes to all the co-authors for friendly collaboration, especially to Docent Antti Mäkitie for offering me the opportunity to start my research in head and neck cancers.

Tumor Bank and colleagues in the Department of Otorhinolaryngology - Head and Neck Surgery, Helsinki University Central Hospital are acknowledged for collecting patient samples.

I warmly thank former and current members in our group for collaboration and friendship. It is an unforgetable experience to work with them. Especially, I wish to thank Dr. Vappu Sirén, who has been taking good care of everything in our office and lab and creating a joyful working atmosphere; Dr. Miina Weckroth for her kind support and many friendly and interesting discussions during the long 
evenings' writing; Dr. Tambet Teesalu for teaching me many things in our lab; Drs. Heli Myöhänen, Satu Mustjoki, Jozef Bizik, DDS Walter Koskinen, as well as Anna Karlsson, M.Sc., Oskari Virtanen, B.Sc. for friendly helps in many ways. Irina Suomalainen and Nina Antikainen are thanked for excellent technical assistance. Docent Marja-Leena Koskiniemi is thanked for her kindness.

I thank Docent Maija Lappalainen who is the first to introduce me to the research in virology, Dr. Heli Piipparinen and Laura Mannonen (M.Sc) for helpful discussions about PCR, Dr. Sami Kukkonen for the help with computers, Leena Kostamovaara for being ready to help with all kinds of technical problems and for interesting discussion about different cultures, Virpi Tiilikainen and Hannele Ståhle for many helps in a way or another.

I thank Dr. Carol Norris for her courses and for author-editing the language of our manuscripts and this thesis.

I warmly thank my friends Pauliina, Johnny, Saara, Pekka, Anna-Maria, Pertti, Jinghui, Tong, and Panu with whom I have shared many happy moments outside the lab. My warmest thank to my mother Fengyi, my stepfather Qiren, my sister Renbing, my brother in law Pingwei, and my niece Wenjing for their longdistance but endless love and encouragement from China. I deeply thank my husband Tauno for his understanding, supporting, and loving me all these years.

The Academy of Finland, Finnish Culture Foundation, Finnish Cancer Institute, Finnish Cancer Societies, Biocentrum Helsinki, Helsinki University Hospital Research Funds, Finnish Foundation for Research on the Ear, Nose, and Throat are thanked for financial support.

Helsinki, June 2004

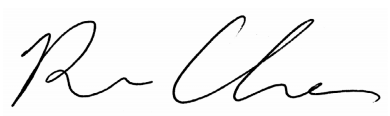




\section{REFERENCES}

Aaltonen LM, Rihkanen H, Vaheri A (2002): Human papillomavirus in larynx. Laryngoscope 112:700-7.

Aaronson SA, Bottaro DP, Miki T, Ron D, Finch PW, Fleming TP, Ahn J, Taylor WG, Rubin JS (1991): Keratinocyte growth factor. A fibroblast growth factor family member with unusual target cell specificity. Ann N Y Acad Sci 638:62-77.

af Geijersstam V, Kibur M, Wang Z, Koskela P, Pukkala E, Schiller J, Lehtinen M, Dillner J (1998): Stability over time of serum antibody levels to human papillomavirus type 16. J Infect Dis 177:1710-4.

Andl T, Kahn T, Pfuhl A, Nicola T, Erber R, Conradt C, Klein W, Helbig M, Dietz A, Weidauer H, Bosch FX (1998): Etiological involvement of oncogenic human papillomavirus in tonsillar squamous cell carcinomas lacking retinoblastoma cell cycle control. Cancer Res 58:5-13.

Androphy EJ (1994): Molecular biology of human papillomavirus infection and oncogenesis. J Invest Dermatol 103:248-56.

Antinore MJ, Birrer MJ, Patel D, Nader L, McCance DJ (1996): The human papillomavirus type $16 \mathrm{E} 7$ gene product interacts with and trans-activates the AP1 family of transcription factors. Embo J 15:1950-60.

Atula S, Grenman R, Syrjanen S (1997): Fibroblasts can modulate the phenotype of malignant epithelial cells in vitro. Exp Cell Res 235:180-7.

Avizienyte E, Loukola A, Roth S, Hemminki A, Tarkkanen M, Salovaara R, Arola J, Butzow R, Husgafvel-Pursiainen K, Kokkola A, Jarvinen H, Aaltonen LA (1999): LKB1 somatic mutations in sporadic tumors. Am J Pathol 154:67781.

Avizienyte E, Roth S, Loukola A, Hemminki A, Lothe RA, Stenwig AE, Fossa SD, Salovaara R, Aaltonen LA (1998): Somatic mutations in LKB1 are rare in sporadic colorectal and testicular tumors. Cancer Res 58:2087-90.

Avvakumov N, Torchia J, Mymryk JS (2003): Interaction of the HPV E7 proteins with the pCAF acetyltransferase. Oncogene 22:3833-41.

Badaracco G, Venuti A, Morello R, Muller A, Marcante ML (2000): Human papillomavirus in head and neck carcinomas: prevalence, physical status and relationship with clinical/pathological parameters. Anticancer Res 20:1301-5. 
Bagchi S, Raychaudhuri P, Nevins JR (1990): Adenovirus E1A proteins can dissociate heteromeric complexes involving the E2F transcription factor: a novel mechanism for E1A trans-activation. Cell 62:659-69.

Baker CC, Phelps WC, Lindgren V, Braun MJ, Gonda MA, Howley PM (1987): Structural and transcriptional analysis of human papillomavirus type 16 sequences in cervical carcinoma cell lines. J Virol 61:962-71.

Balz V, Scheckenbach K, Gotte K, Bockmuhl U, Petersen I, Bier H (2003): Is the p53 inactivation frequency in squamous cell carcinomas of the head and neck underestimated? Analysis of p53 exons 2-11 and human papillomavirus 16/18 E6 transcripts in 123 unselected tumor specimens. Cancer Res 63:1188-91.

Band V, Dalal S, Delmolino L, Androphy EJ (1993): Enhanced degradation of p53 protein in HPV-6 and BPV-1 E6-immortalized human mammary epithelial cells. Embo J 12:1847-52.

Band V, De Caprio JA, Delmolino L, Kulesa V, Sager R (1991): Loss of p53 protein in human papillomavirus type 16 E6-immortalized human mammary epithelial cells. J Virol 65:6671-6.

Bandara LR, Adamczewski JP, Hunt T, La Thangue NB (1991): Cyclin A and the retinoblastoma gene product complex with a common transcription factor. Nature 352:249-51.

Barbosa MS, Lowy DR, Schiller JT (1989): Papillomavirus polypeptides E6 and E7 are zinc-binding proteins. J Virol 63:1404-7.

Barten M, Ostwald C, Milde-Langosch K, Muller P, Wukasch Y, Loning T (1995): HPV DNA and p53 alterations in oropharyngeal carcinomas. Virchows Arch 427:153-7.

Bauer HM, Ting Y, Greer CE, Chambers JC, Tashiro CJ, Chimera J, Reingold A, Manos MM (1991): Genital human papillomavirus infection in female university students as determined by a PCR-based method. Jama 265:472-7.

Beaudenon S, Kremsdorf D, Croissant O, Jablonska S, Wain-Hobson S, Orth G (1986): A novel type of human papillomavirus associated with genital neoplasias. Nature 321:246-9.

Bignell GR, Barfoot R, Seal S, Collins N, Warren W, Stratton MR (1998): Low frequency of somatic mutations in the LKB1/Peutz-Jeghers syndrome gene in sporadic breast cancer. Cancer Res 58:1384-6. 
Blanton RA, Perez-Reyes N, Merrick DT, McDougall JK (1991): Epithelial cells immortalized by human papillomaviruses have premalignant characteristics in organotypic culture. Am J Pathol 138:673-85.

Blons H, Laurent-Puig P (2003): TP53 and head and neck neoplasms. Hum Mutat 21:252-7.

Boshart M, Gissmann L, Ikenberg H, Kleinheinz A, Scheurlen W, zur Hausen H (1984): A new type of papillomavirus DNA, its presence in genital cancer biopsies and in cell lines derived from cervical cancer. Embo J 3:1151-7.

Bouvard V, Storey A, Pim D, Banks L (1994): Characterization of the human papillomavirus E2 protein: evidence of trans-activation and transrepression in cervical keratinocytes. Embo J 13:5451-9.

Brandsma JL, Abramson AL (1989): Association of papillomavirus with cancers of the head and neck. Arch Otolaryngol Head Neck Surg 115:621-5.

Brehm A, Nielsen SJ, Miska EA, McCance DJ, Reid JL, Bannister AJ, Kouzarides T (1999): The E7 oncoprotein associates with Mi2 and histone deacetylase activity to promote cell growth. Embo J 18:2449-58.

Califano J, van der Riet P, Westra W, Nawroz H, Clayman G, Piantadosi S, Corio R, Lee D, Greenberg B, Koch W, Sidransky D (1996): Genetic progression model for head and neck cancer: implications for field cancerization. Cancer Res 56:2488-92.

Carter JJ, Koutsky LA, Hughes JP, Lee SK, Kuypers J, Kiviat N, Galloway DA (2000): Comparison of human papillomavirus types 16, 18, and 6 capsid antibody responses following incident infection. J Infect Dis 181:1911-9.

Carter JJ, Koutsky LA, Wipf GC, Christensen ND, Lee SK, Kuypers J, Kiviat N, Galloway DA (1996): The natural history of human papillomavirus type 16 capsid antibodies among a cohort of university women. J Infect Dis 174:927-36.

Carter JJ, Wipf GC, Hagensee ME, McKnight B, Habel LA, Lee SK, Kuypers J, Kiviat N, Daling JR, Koutsky LA, et al. (1995): Use of human papillomavirus type 6 capsids to detect antibodies in people with genital warts. J Infect Dis 172:11-8.

Chakrabarti O, Krishna S (2003): Molecular interactions of 'high risk' human papillomaviruses E6 and E7 oncoproteins: implications for tumour progression. J Biosci 28:337-48. 
Chen PC, Kuo C, Pan CC, Chou MY (2002): Risk of oral cancer associated with human papillomavirus infection, betel quid chewing, and cigarette smoking in Taiwan--an integrated molecular and epidemiological study of 58 cases. J Oral Pathol Med 31:317-22.

Chen Q, Samaranayake LP, Zhou H, Xiao L (2000): Homozygous deletion of the PTEN tumor-suppressor gene is not a feature in oral squamous cell carcinoma. Oral Oncol 36:95-9.

Chiba I, Shindoh M, Yasuda M, Yamazaki Y, Amemiya A, Sato Y, Fujinaga K, Notani K, Fukuda H (1996): Mutations in the p53 gene and human papillomavirus infection as significant prognostic factors in squamous cell carcinomas of the oral cavity. Oncogene 12:1663-8.

Chow LT, Broker TR (1994): Papillomavirus DNA replication. Intervirology 37:150-8.

Cripe TP, Haugen TH, Turk JP, Tabatabai F, Schmid PG, 3rd, Durst M, Gissmann L, Roman A, Turek LP (1987): Transcriptional regulation of the human papillomavirus-16 E6-E7 promoter by a keratinocyte-dependent enhancer, and by viral E2 trans-activator and repressor gene products: implications for cervical carcinogenesis. Embo J 6:3745-53.

Dai M, Clifford GM, le Calvez F, Castellsague X, Snijders PJ, Pawlita M, Herrero R, Hainaut P, Franceschi S (2004): Human papillomavirus type 16 and TP53 mutation in oral cancer: matched analysis of the IARC multicenter study. Cancer Res 64:468-71.

Daniel B, Mukherjee G, Seshadri L, Vallikad E, Krishna S (1995): Changes in the physical state and expression of human papillomavirus type 16 in the progression of cervical intraepithelial neoplasia lesions analysed by PCR. J Gen Virol 76 ( Pt 10):2589-93.

de Gruijl TD, Bontkes HJ, Walboomers JM, Schiller JT, Stukart MJ, Groot BS, Chabaud MM, Remmink AJ, Verheijen RH, Helmerhorst TJ, Meijer CJ, Scheper RJ (1997): Immunoglobulin $G$ responses against human papillomavirus type 16 virus-like particles in a prospective nonintervention cohort study of women with cervical intraepithelial neoplasia. J Natl Cancer Inst 89:630-8.

de Villiers EM (1997): Papillomavirus and HPV typing. Clin Dermatol 15:199-206.

de Villiers EM, Fauquet C, Broker TR, Bernard H-U, zur Hausen H (2004): Classification of papillomaviruses. Virology in press. 
de Villiers EM, Weidauer H, Otto H, zur Hausen H (1985): Papillomavirus DNA in human tongue carcinomas. Int J Cancer 36:575-8.

Decker J, Goldstein JC (1982): Risk factors in head and neck cancer. N Engl J Med 306:1151-5.

Dhawan P, Bell A, Kumar A, Golden C, Mehta KD (1999): Critical role of p42/44(MAPK) activation in anisomycin and hepatocyte growth factorinduced LDL receptor expression: activation of Raf-1/Mek$1 / \mathrm{p} 42 / 44$ (MAPK) cascade alone is sufficient to induce LDL receptor expression. J Lipid Res 40:1911-9.

Dillner J, Kallings I, Brihmer C, Sikstrom B, Koskela P, Lehtinen M, Schiller JT, Sapp M, Mardh PA (1996): Seropositivities to human papillomavirus types 16,18 , or 33 capsids and to Chlamydia trachomatis are markers of sexual behavior. J Infect Dis 173:1394-8.

Doorbar J, Ely S, Sterling J, McLean C, Crawford L (1991): Specific interaction between HPV-16 E1-E4 and cytokeratins results in collapse of the epithelial cell intermediate filament network. Nature 352:824-7.

Doorbar J, Gallimore PH (1987): Identification of proteins encoded by the L1 and L2 open reading frames of human papillomavirus 1a. J Virol 61:2793-9.

Duensing S, Duensing A, Crum CP, Munger K (2001): Human papillomavirus type 16 E7 oncoprotein-induced abnormal centrosome synthesis is an early event in the evolving malignant phenotype. Cancer Res 61:2356-60.

Duensing S, Lee LY, Duensing A, Basile J, Piboonniyom S, Gonzalez S, Crum CP, Munger K (2000): The human papillomavirus type 16 E6 and E7 oncoproteins cooperate to induce mitotic defects and genomic instability by uncoupling centrosome duplication from the cell division cycle. Proc Natl Acad Sci U S A 97:10002-7.

Dürst M, Croce CM, Gissmann L, Schwarz E, Huebner K (1987a): Papillomavirus sequences integrate near cellular oncogenes in some cervical carcinomas. Proc Natl Acad Sci U S A 84:1070-4.

Dürst M, Dzarlieva-Petrusevska RT, Boukamp P, Fusenig NE, Gissmann L (1987b): Molecular and cytogenetic analysis of immortalized human primary keratinocytes obtained after transfection with human papillomavirus type 16 DNA. Oncogene 1:251-6.

Dürst M, Gissmann L, Ikenberg H, zur Hausen H (1983): A papillomavirus DNA from a cervical carcinoma and its prevalence in cancer biopsy samples from different geographic regions. Proc Natl Acad Sci U S A 80:3812-5. 
Dürst M, Seagon S, Wanschura S, zur Hausen H, Bullerdiek J (1995): Malignant progression of an HPV16-immortalized human keratinocyte cell line (HPKIA) in vitro. Cancer Genet Cytogenet 85:105-12.

Dyson N, Howley PM, Munger K, Harlow E (1989): The human papilloma virus16 E7 oncoprotein is able to bind to the retinoblastoma gene product. Science 243:934-7.

Fallani MG, Pirami L, Penna C, Giache V, Zipoli E, Cardelli A, Marchionni M, Becciolini A (1997): [Cervical intraepithelial neoplasia (CIN) and human papillomavirus (HPV) infection]. Minerva Ginecol 49:13-8.

Finch PW, Rubin JS, Miki T, Ron D, Aaronson SA (1989): Human KGF is FGFrelated with properties of a paracrine effector of epithelial cell growth. Science 245:752-5.

Finnish Cancer Registry (2002): Cancer Incidence in Finland. Helsinki: Finnish Cancer Registry - Institute for Statistical and Epidemiological Cancer Research 50 years 1952-2002.

Forastiere A, Koch W, Trotti A, Sidransky D (2001): Head and neck cancer. N Engl J Med 345:1890-900.

Forastiere AA, Goepfert H, Maor M, Pajak TF, Weber R, Morrison W, Glisson B, Trotti A, Ridge JA, Chao C, Peters G, Lee DJ, Leaf A, Ensley J, Cooper J (2003): Concurrent chemotherapy and radiotherapy for organ preservation in advanced laryngeal cancer. N Engl J Med 349:2091-8.

Franceschi S, Talamini R, Barra S, Baron AE, Negri E, Bidoli E, Serraino D, La Vecchia C (1990): Smoking and drinking in relation to cancers of the oral cavity, pharynx, larynx, and esophagus in northern Italy. Cancer Res 50:6502-7.

Frattini MG, Lim HB, Laimins LA (1996): In vitro synthesis of oncogenic human papillomaviruses requires episomal genomes for differentiation-dependent late expression. Proc Natl Acad Sci U S A 93:3062-7.

Frisch M, Biggar RJ (1999): Aetiological parallel between tonsillar and anogenital squamous-cell carcinomas. Lancet 354:1442-3.

Fukushima K, Ogura H, Watanabe S, Yabe Y, Masuda Y (1994): Human papillomavirus type 16 DNA detected by the polymerase chain reaction in non-cancer tissues of the head and neck. Eur Arch Otorhinolaryngol 251:109-12. 
Funk JO, Waga S, Harry JB, Espling E, Stillman B, Galloway DA (1997): Inhibition of CDK activity and PCNA-dependent DNA replication by p21 is blocked by interaction with the HPV-16 E7 oncoprotein. Genes Dev 11:2090-100.

Gardiol D, Kuhne C, Glaunsinger B, Lee SS, Javier R, Banks L (1999): Oncogenic human papillomavirus E6 proteins target the discs large tumour suppressor for proteasome-mediated degradation. Oncogene 18:5487-96.

Gasco M, Crook T (2003): The p53 network in head and neck cancer. Oral Oncol 39:222-31.

Gasparotto D, Vukosavljevic T, Piccinin S, Barzan L, Sulfaro S, Armellin M, Boiocchi M, Maestro R (1999): Loss of heterozygosity at 10q in tumors of the upper respiratory tract is associated with poor prognosis. Int J Cancer $84: 432-6$.

Genther SM, Sterling S, Duensing S, Munger K, Sattler C, Lambert PF (2003): Quantitative role of the human papillomavirus type 16 E5 gene during the productive stage of the viral life cycle. J Virol 77:2832-42.

Gewin L, Galloway DA (2001): E box-dependent activation of telomerase by human papillomavirus type 16 E6 does not require induction of c-myc. J Virol 75:7198-201.

Gillison ML, Koch WM, Capone RB, Spafford M, Westra WH, Wu L, Zahurak ML, Daniel RW, Viglione M, Symer DE, Shah KV, Sidransky D (2000): Evidence for a causal association between human papillomavirus and a subset of head and neck cancers. J Natl Cancer Inst 92:709-20.

Gillison ML, Koch WM, Shah KV (1999): Human papillomavirus in head and neck squamous cell carcinoma: are some head and neck cancers a sexually transmitted disease? Curr Opin Oncol 11:191-9.

Glaunsinger BA, Lee SS, Thomas M, Banks L, Javier R (2000): Interactions of the PDZ-protein MAGI-1 with adenovirus E4-ORF1 and high-risk papillomavirus E6 oncoproteins. Oncogene 19:5270-80.

Greer RO, Jr., Popper HA, DeMento FJ (1976): Cowden's disease (multiple hamartoma syndrome). Report of a limited mucocutaneous form. J Periodontol 47:531-4.

Greider CW, Blackburn EH (1985): Identification of a specific telomere terminal transferase activity in Tetrahymena extracts. Cell 43:405-13.

Ha PK, Pai SI, Westra WH, Gillison ML, Tong BC, Sidransky D, Califano JA (2002): Real-time quantitative PCR demonstrates low prevalence of human 
papillomavirus type 16 in premalignant and malignant lesions of the oral cavity. Clin Cancer Res 8:1203-9.

Halbert CL, Demers GW, Galloway DA (1991): The E7 gene of human papillomavirus type 16 is sufficient for immortalization of human epithelial cells. J Virol 65:473-8.

Halbert CL, Demers GW, Galloway DA (1992): The E6 and E7 genes of human papillomavirus type 6 have weak immortalizing activity in human epithelial cells. J Virol 66:2125-34.

Hamsikova E, Ludvikova V, Smahel M, Sapp M, Vonka V (1998): Prevalence of antibodies to human papillomaviruses in the general population of the Czech Republic. Int J Cancer 77:689-94.

Hawley-Nelson P, Vousden KH, Hubbert NL, Lowy DR, Schiller JT (1989): HPV16 E6 and E7 proteins cooperate to immortalize human foreskin keratinocytes. Embo J 8:3905-10.

Hemminki A, Markie D, Tomlinson I, Avizienyte E, Roth S, Loukola A, Bignell G, Warren W, Aminoff M, Hoglund P, Jarvinen H, Kristo P, Pelin K, Ridanpaa M, Salovaara R, Toro T, Bodmer W, Olschwang S, Olsen AS, Stratton MR, de la Chapelle A, Aaltonen LA (1998): A serine/threonine kinase gene defective in Peutz-Jeghers syndrome. Nature 391:184-7.

Henderson YC, Wang E, Clayman GL (1998): Genotypic analysis of tumor suppressor genes PTEN/MMAC1 and p53 in head and neck squamous cell carcinomas. Laryngoscope 108:1553-6.

Herrero R, Castellsague X, Pawlita M, Lissowska J, Kee F, Balaram P, Rajkumar T, Sridhar H, Rose B, Pintos J, Fernandez L, Idris A, Sanchez MJ, Nieto A, Talamini R, Tavani A, Bosch FX, Reidel U, Snijders PJ, Meijer CJ, Viscidi R, Munoz N, Franceschi S (2003): Human papillomavirus and oral cancer: the International Agency for Research on Cancer multicenter study. J Natl Cancer Inst 95:1772-83.

Hietanen S, Auvinen E, Syrjanen K, Syrjanen S (1998): Anti-proliferative effect of retinoids and interferon-alpha-2a on vaginal cell lines derived from squamous intra-epithelial lesions. Int J Cancer 78:338-45.

Holt SE, Schuller G, Wilson VG (1994): DNA binding specificity of the bovine papillomavirus E1 protein is determined by sequences contained within an 18-base-pair inverted repeat element at the origin of replication. J Virol 68:1094-102. 
Hu YC, Lam KY, Tang JC, Srivastava G (1999): Mutational analysis of the PTEN/MMAC1 gene in primary oesophageal squamous cell carcinomas. Mol Pathol 52:353-6.

Hukku B, Mally M, Cher ML, Peehl DM, Kung H, Rhim JS (2000): Stepwise genetic changes associated with progression of nontumorigenic HPV-18 immortalized human prostate cancer-derived cell line to a malignant phenotype. Cancer Genet Cytogenet 120:117-26.

IARC (1995): Monograph on the evaluation of carcinogenic risks to humans, Vol 64. Lyon: IARC.

Jenne DE, Reimann H, Nezu J, Friedel W, Loff S, Jeschke R, Muller O, Back W, Zimmer M (1998): Peutz-Jeghers syndrome is caused by mutations in a novel serine threonine kinase. Nat Genet 18:38-43.

Jeon S, Lambert PF (1995): Integration of human papillomavirus type 16 DNA into the human genome leads to increased stability of E6 and E7 mRNAs: implications for cervical carcinogenesis. Proc Natl Acad Sci U S A 92:16548.

Jones DL, Alani RM, Munger K (1997): The human papillomavirus E7 oncoprotein can uncouple cellular differentiation and proliferation in human keratinocytes by abrogating p21Cip1-mediated inhibition of cdk2. Genes Dev 11:2101-11.

Jordanova A, Kalaydjieva L, Savov A, Claustres M, Schwarz M, Estivill X, Angelicheva D, Haworth A, Casals T, Kremensky I (1997): SSCP analysis: a blind sensitivity trial. Hum Mutat 10:65-70.

Kabsch K, Alonso A (2002): The human papillomavirus type 16 (HPV-16) E5 protein sensitizes human keratinocytes to apoptosis induced by osmotic stress. Oncogene 21:947-53.

Kahn T, Turazza E, Ojeda R, Bercovich A, Stremlau A, Lichter P, Poustka A, Grinstein S, zur Hausen H (1994): Integration of human papillomavirus type 6a DNA in a tonsillar carcinoma: chromosomal localization and nucleotide sequence of the genomic target region. Cancer Res 54:1305-12.

Kalantari M, Karlsen F, Kristensen G, Holm R, Hagmar B, Johansson B (1998): Disruption of the E1 and E2 reading frames of HPV 16 in cervical carcinoma is associated with poor prognosis. Int J Gynecol Pathol 17:14653. 
Kim NW, Piatyszek MA, Prowse KR, Harley CB, West MD, Ho PL, Coviello GM, Wright WE, Weinrich SL, Shay JW (1994): Specific association of human telomerase activity with immortal cells and cancer. Science 266:2011-5.

Kiyono T, Foster SA, Koop JI, McDougall JK, Galloway DA, Klingelhutz AJ (1998): Both $\mathrm{Rb} / \mathrm{p} 16 \mathrm{INK} 4 \mathrm{a}$ inactivation and telomerase activity are required to immortalize human epithelial cells. Nature 396:84-8.

Kiyono T, Hiraiwa A, Fujita M, Hayashi Y, Akiyama T, Ishibashi M (1997): Binding of high-risk human papillomavirus E6 oncoproteins to the human homologue of the Drosophila discs large tumor suppressor protein. Proc Natl Acad Sci U S A 94:11612-6.

Klingelhutz AJ, Foster SA, McDougall JK (1996): Telomerase activation by the E6 gene product of human papillomavirus type 16. Nature 380:79-82.

Klussmann JP, Gultekin E, Weissenborn SJ, Wieland U, Dries V, Dienes HP, Eckel HE, Pfister HJ, Fuchs PG (2003): Expression of p16 Protein Identifies a Distinct Entity of Tonsillar Carcinomas Associated with Human Papillomavirus. Am J Pathol 162:747-53.

Klussmann JP, Weissenborn SJ, Wieland U, Dries V, Kolligs J, Jungehuelsing M, Eckel HE, Dienes HP, Pfister HJ, Fuchs PG (2001): Prevalence, distribution, and viral load of human papillomavirus 16 DNA in tonsillar carcinomas. Cancer 92:2875-84.

Koopman LA, Szuhai K, van Eendenburg JD, Bezrookove V, Kenter GG, Schuuring E, Tanke H, Fleuren GJ (1999): Recurrent integration of human papillomaviruses 16, 45, and 67 near translocation breakpoints in new cervical cancer cell lines. Cancer Res 59:5615-24.

LaRochelle WJ, Sakaguchi K, Atabey N, Cheon HG, Takagi Y, Kinaia T, Day RM, Miki T, Burgess WH, Bottaro DP (1999): Heparan sulfate proteoglycan modulates keratinocyte growth factor signaling through interaction with both ligand and receptor. Biochemistry 38:1765-71.

Lee JI, Soria JC, Hassan KA, El-Naggar AK, Tang X, Liu DD, Hong WK, Mao L (2001): Loss of PTEN expression as a prognostic marker for tongue cancer. Arch Otolaryngol Head Neck Surg 127:1441-5.

Lee SS, Glaunsinger B, Mantovani F, Banks L, Javier RT (2000): Multi-PDZ domain protein MUPP1 is a cellular target for both adenovirus E4-ORF1 and highrisk papillomavirus type 18 E6 oncoproteins. J Virol 74:9680-93. 
Lee SS, Weiss RS, Javier RT (1997): Binding of human virus oncoproteins to hDlg/SAP97, a mammalian homolog of the Drosophila discs large tumor suppressor protein. Proc Natl Acad Sci U S A 94:6670-5.

Leptak C, Ramon y Cajal S, Kulke R, Horwitz BH, Riese DJ, 2nd, Dotto GP, DiMaio D (1991): Tumorigenic transformation of murine keratinocytes by the E5 genes of bovine papillomavirus type 1 and human papillomavirus type 16. J Virol 65:7078-83.

Li DM, Sun H (1997): TEP1, encoded by a candidate tumor suppressor locus, is a novel protein tyrosine phosphatase regulated by transforming growth factor beta. Cancer Res 57:2124-9.

Li J, Yen C, Liaw D, Podsypanina K, Bose S, Wang SI, Puc J, Miliaresis C, Rodgers L, McCombie R, Bigner SH, Giovanella BC, Ittmann M, Tycko B, Hibshoosh H, Wigler MH, Parsons R (1997): PTEN, a putative protein tyrosine phosphatase gene mutated in human brain, breast, and prostate cancer. Science 275:1943-7.

Li W, Thompson CH, Cossart YE, O'Brien CJ, McNeil EB, Scolyer RA, Rose BR (2004): The expression of key cell cycle markers and presence of human papillomavirus in squamous cell carcinoma of the tonsil. Head Neck 26:1-9.

Li W, Thompson CH, O'Brien CJ, McNeil EB, Scolyer RA, Cossart YE, Veness MJ, Walker DM, Morgan GJ, Rose BR (2003): Human papillomavirus positivity predicts favourable outcome for squamous carcinoma of the tonsil. Int J Cancer 106:553-8.

Liaw D, Marsh DJ, Li J, Dahia PL, Wang SI, Zheng Z, Bose S, Call KM, Tsou HC, Peacocke M, Eng C, Parsons R (1997): Germline mutations of the PTEN gene in Cowden disease, an inherited breast and thyroid cancer syndrome. Nat Genet 16:64-7.

Licitra L, Bernier J, Grandi C, Merlano M, Bruzzi P, Lefebvre JL (2002): Cancer of the oropharynx. Crit Rev Oncol Hematol 41:107-22.

Liu Y, Chen JJ, Gao Q, Dalal S, Hong Y, Mansur CP, Band V, Androphy EJ (1999): Multiple functions of human papillomavirus type $16 \mathrm{E} 6$ contribute to the immortalization of mammary epithelial cells. J Virol 73:7297-307.

Lorincz AT, Lancaster WD, Temple GF (1986): Cloning and characterization of the DNA of a new human papillomavirus from a woman with dysplasia of the uterine cervix. J Virol 58:225-9.

Luft F, Klaes R, Nees M, Durst M, Heilmann V, Melsheimer P, von Knebel Doeberitz M (2001): Detection of integrated papillomavirus sequences by 
ligation-mediated PCR (DIPS-PCR) and molecular characterization in cervical cancer cells. Int J Cancer 92:9-17.

Luukkaa M, Minn H, Aitasalo K, Kronqvist P, Kulmala J, Pyrhönen S, Grenman R (2003): Treatment of squamous cell carcinoma of the oral cavity, oropharynx and hypopharynx--an analysis of 174 patients in south western Finland. Acta Oncol 42:756-62.

Löning T, Ikenberg H, Becker J, Gissmann L, Hoepfer I, zur Hausen H (1985): Analysis of oral papillomas, leukoplakias, and invasive carcinomas for human papillomavirus type related DNA. J Invest Dermatol 84:417-20.

Mantovani F, Banks L (2001): The human papillomavirus E6 protein and its contribution to malignant progression. Oncogene 20:7874-87.

Mao L, Hong WK, Papadimitrakopoulou VA (2004): Focus on head and neck cancer. Cancer Cell 5:311-6.

Mavros A, Hahn M, Wieland I, Koy S, Koufaki ON, Strelocke K, Koch R, Haroske G, Schackert HK, Eckelt U (2002): Infrequent genetic alterations of the tumor suppressor gene PTEN/MMAC1 in squamous cell carcinoma of the oral cavity. J Oral Pathol Med 31:270-6.

McDougall JK (1994): Immortalization and transformation of human cells by human papillomavirus. Curr Top Microbiol Immunol 186:101-19.

McKaig RG, Baric RS, Olshan AF (1998): Human papillomavirus and head and neck cancer: epidemiology and molecular biology. Head Neck 20:250-65.

Mellin H, Dahlgren L, Munck-Wikland E, Lindholm J, Rabbani H, Kalantari M, Dalianis T (2002): Human papillomavirus type 16 is episomal and a high viral load may be correlated to better prognosis in tonsillar cancer. Int J Cancer 102:152-8.

Mellin H, Friesland S, Lewensohn R, Dalianis T, Munck-Wikland E (2000): Human papillomavirus (HPV) DNA in tonsillar cancer: clinical correlates, risk of relapse, and survival. Int J Cancer 89:300-4.

Meyers C, Bromberg-White JL, Zhang J, Kaupas ME, Bryan JT, Lowe RS, Jansen KU (2002): Infectious virions produced from a human papillomavirus type 18/16 genomic DNA chimera. J Virol 76:4723-33.

Meyers C, Frattini MG, Hudson JB, Laimins LA (1992): Biosynthesis of human papillomavirus from a continuous cell line upon epithelial differentiation. Science 257:971-3. 
Miller CS, Johnstone BM (2001): Human papillomavirus as a risk factor for oral squamous cell carcinoma: a meta-analysis, 1982-1997. Oral Surg Oral Med Oral Pathol Oral Radiol Endod 91:622-35.

Mork J, Lie AK, Glattre E, Hallmans G, Jellum E, Koskela P, Moller B, Pukkala E, Schiller JT, Youngman L, Lehtinen M, Dillner J (2001): Human papillomavirus infection as a risk factor for squamous-cell carcinoma of the head and neck. N Engl J Med 344:1125-31.

Muller M, Viscidi RP, Ulken V, Bavinck JN, Hill PM, Fisher SG, Reid R, Munoz N, Schneider A, Shah KV, et al. (1995): Antibodies to the E4, E6, and E7 proteins of human papillomavirus (HPV) type 16 in patients with HPVassociated diseases and in the normal population. J Invest Dermatol 104:138-41.

Mund K, Han C, Daum R, Helfrich S, Muller M, Fisher SG, Schiller JT, Gissmann L (1997): Detection of human papillomavirus type 16 DNA and of antibodies to human papillomavirus type 16 proteins in children. Intervirology 40:232-7.

Munger K, Basile JR, Duensing S, Eichten A, Gonzalez SL, Grace M, Zacny VL (2001): Biological activities and molecular targets of the human papillomavirus E7 oncoprotein. Oncogene 20:7888-98.

Munger K, Phelps WC, Bubb V, Howley PM, Schlegel R (1989): The E6 and E7 genes of the human papillomavirus type 16 together are necessary and sufficient for transformation of primary human keratinocytes. J Virol 63:4417-21.

Munoz N, Bosch FX, de Sanjose S, Herrero R, Castellsague X, Shah KV, Snijders PJ, Meijer CJ (2003): Epidemiologic classification of human papillomavirus types associated with cervical cancer. N Engl J Med 348:518-27.

Nakagawa S, Huibregtse JM (2000): Human scribble (Vartul) is targeted for ubiquitin-mediated degradation by the high-risk papillomavirus E6 proteins and the E6AP ubiquitin-protein ligase. Mol Cell Biol 20:8244-53.

Netter (2001): Atlas of Human Anatomy. New jersey: ICON Learning Systems, LLC.

Niedobitek G, Pitteroff S, Herbst H, Shepherd P, Finn T, Anagnostopoulos I, Stein $\mathrm{H}$ (1990): Detection of human papillomavirus type 16 DNA in carcinomas of the palatine tonsil. J Clin Pathol 43:918-21.

Nishioka S, Fukushima K, Nishizaki K, Gunduz M, Tominaga S, Fukazawa M, Monden N, Watanabe S, Masuda Y, Ogura H (1999): Human 
papillomavirus as a risk factor for head and neck cancers--a case-control study. Acta Otolaryngol Suppl 540:77-80.

Okami K, Wu L, Riggins G, Cairns P, Goggins M, Evron E, Halachmi N, Ahrendt SA, Reed AL, Hilgers W, Kern SE, Koch WM, Sidransky D, Jen J (1998): Analysis of PTEN/MMAC1 alterations in aerodigestive tract tumors. Cancer Res 58:509-11.

Olumi AF, Grossfeld GD, Hayward SW, Carroll PR, Tlsty TD, Cunha GR (1999): Carcinoma-associated fibroblasts direct tumor progression of initiated human prostatic epithelium. Cancer Res 59:5002-11.

Park WS, Moon YW, Yang YM, Kim YS, Kim YD, Fuller BG, Vortmeyer AO, Fogt F, Lubensky IA, Zhuang Z (1998): Mutations of the STK11 gene in sporadic gastric carcinoma. Int J Oncol 13:601-4.

Parkin DM, Pisani P, Ferlay J (1999): Estimates of the worldwide incidence of 25 major cancers in 1990. Int J Cancer 80:827-41.

Paz IB, Cook N, Odom-Maryon T, Xie Y, Wilczynski SP (1997): Human papillomavirus (HPV) in head and neck cancer. An association of HPV 16 with squamous cell carcinoma of Waldeyer's tonsillar ring. Cancer 79:595604.

Peitsaro P, Johansson B, Syrjanen S (2002): Integrated human papillomavirus type 16 is frequently found in cervical cancer precursors as demonstrated by a novel quantitative real-time PCR technique. J Clin Microbiol 40:886-91.

Pfister H (2003): Chapter 8: Human papillomavirus and skin cancer. J Natl Cancer Inst Monogr:52-6.

Phillips P, Spigelman A, Thompson J (1994): Familial adenomatous polyposis and other polyposis syndromes. London: Edvard Arnold.

Pim D, Collins M, Banks L (1992): Human papillomavirus type 16 E5 gene stimulates the transforming activity of the epidermal growth factor receptor. Oncogene 7:27-32.

Pintos J, Franco EL, Black MJ, Bergeron J, Arella M (1999): Human papillomavirus and prognoses of patients with cancers of the upper aerodigestive tract. Cancer 85:1903-9.

Poetsch M, Lorenz G, Kleist B (2002): Detection of new PTEN/MMAC1 mutations in head and neck squamous cell carcinomas with loss of chromosome 10. Cancer Genet Cytogenet 132:20-4. 
Popescu NC, DiPaolo JA (1990): Integration of human papillomavirus 16 DNA and genomic rearrangements in immortalized human keratinocyte lines. Cancer Res 50:1316-23.

Resta N, Simone C, Mareni C, Montera M, Gentile M, Susca F, Gristina R, Pozzi S, Bertario L, Bufo P, Carlomagno N, Ingrosso M, Rossini FP, Tenconi R, Guanti G (1998): STK11 mutations in Peutz-Jeghers syndrome and sporadic colon cancer. Cancer Res 58:4799-801.

Reuter S, Bartelmann M, Vogt M, Geisen C, Napierski I, Kahn T, Delius H, Lichter P, Weitz S, Korn B, Schwarz E (1998): APM-1, a novel human gene, identified by aberrant co-transcription with papillomavirus oncogenes in a cervical carcinoma cell line, encodes a BTB/POZ-zinc finger protein with growth inhibitory activity. Embo J 17:215-22.

Ridley AJ, Comoglio PM, Hall A (1995): Regulation of scatter factor/hepatocyte growth factor responses by Ras, Rac, and Rho in MDCK cells. Mol Cell Biol 15:1110-22.

Ringstrom E, Peters E, Hasegawa M, Posner M, Liu M, Kelsey KT (2002): Human papillomavirus type 16 and squamous cell carcinoma of the head and neck. Clin Cancer Res 8:3187-92.

Scheffner M, Huibregtse JM, Vierstra RD, Howley PM (1993): The HPV-16 E6 and E6-AP complex functions as a ubiquitin-protein ligase in the ubiquitination of p53. Cell 75:495-505.

Scheffner M, Werness BA, Huibregtse JM, Levine AJ, Howley PM (1990): The E6 oncoprotein encoded by human papillomavirus types 16 and 18 promotes the degradation of p53. Cell 63:1129-36.

Scheffner M, Whitaker NJ (2003): Human papillomavirus-induced carcinogenesis and the ubiquitin-proteasome system. Semin Cancer Biol 13:59-67.

Scholes AG, Liloglou T, Snijders PJ, Hart CA, Jones AS, Woolgar JA, Vaughan ED, Walboomers JM, Field JK (1997): p53 mutations in relation to human papillomavirus type 16 infection in squamous cell carcinomas of the head and neck. Int J Cancer 71:796-9.

Schwartz SM, Daling JR, Doody DR, Wipf GC, Carter JJ, Madeleine MM, Mao EJ, Fitzgibbons ED, Huang S, Beckmann AM, McDougall JK, Galloway DA (1998): Oral cancer risk in relation to sexual history and evidence of human papillomavirus infection. J Natl Cancer Inst 90:1626-36. 
Schwarz E, Freese UK, Gissmann L, Mayer W, Roggenbuck B, Stremlau A, zur Hausen H (1985): Structure and transcription of human papillomavirus sequences in cervical carcinoma cells. Nature 314:111-4.

Shah KV, Viscidi RP, Alberg AJ, Helzlsouer KJ, Comstock GW (1997): Antibodies to human papillomavirus 16 and subsequent in situ or invasive cancer of the cervix. Cancer Epidemiol Biomarkers Prev 6:233-7.

Shao X, Tandon R, Samara G, Kanki H, Yano H, Close LG, Parsons R, Sato T (1998): Mutational analysis of the PTEN gene in head and neck squamous cell carcinoma. Int J Cancer 77:684-8.

Shay JW, Bacchetti S (1997): A survey of telomerase activity in human cancer. Eur J Cancer 33:787-91.

Shin KH, Kim JM, Rho KS, Park KH, Oh JE, Min BM (2002): Inactivation of the PTEN gene by mutation, exonic deletion, and loss of transcript in human oral squamous cell carcinomas. Int J Oncol 21:997-1001.

Smith EM, Pignatari SS, Gray SD, Haugen TH, Turek LP (1993): Human papillomavirus infection in papillomas and nondiseased respiratory sites of patients with recurrent respiratory papillomatosis using the polymerase chain reaction. Arch Otolaryngol Head Neck Surg 119:554-7.

Smith EM, Ritchie JM, Summersgill KF, Hoffman HT, Wang DH, Haugen TH, Turek LP (2004): Human papillomavirus in oral exfoliated cells and risk of head and neck cancer. J Natl Cancer Inst 96:449-55.

Smith PP, Friedman CL, Bryant EM, McDougall JK (1992): Viral integration and fragile sites in human papillomavirus-immortalized human keratinocyte cell lines. Genes Chromosomes Cancer 5:150-7.

Snijders PJ, Cromme FV, van den Brule AJ, Schrijnemakers HF, Snow GB, Meijer CJ, Walboomers JM (1992): Prevalence and expression of human papillomavirus in tonsillar carcinomas, indicating a possible viral etiology. Int J Cancer 51:845-50.

Snijders PJ, Scholes AG, Hart CA, Jones AS, Vaughan ED, Woolgar JA, Meijer CJ, Walboomers JM, Field JK (1996): Prevalence of mucosotropic human papillomaviruses in squamous-cell carcinoma of the head and neck. Int J Cancer 66:464-9.

Song S, Liem A, Miller JA, Lambert PF (2000): Human papillomavirus types 16 E6 and E7 contribute differently to carcinogenesis. Virology 267:141-50. 
Song S, Pitot HC, Lambert PF (1999): The human papillomavirus type 16 E6 gene alone is sufficient to induce carcinomas in transgenic animals. J Virol 73:5887-93.

Spitz MR (1994): Epidemiology and risk factors for head and neck cancer. Semin Oncol 21:281-8.

Squarize CH, Castilho RM, Santos Pinto D, Jr. (2002): Immunohistochemical evidence of PTEN in oral squamous cell carcinoma and its correlation with the histological malignancy grading system. J Oral Pathol Med 31:379-84.

Stanley MA, Browne HM, Appleby M, Minson AC (1989): Properties of a nontumorigenic human cervical keratinocyte cell line. Int J Cancer 43:672-6.

Steck PA, Pershouse MA, Jasser SA, Yung WK, Lin H, Ligon AH, Langford LA, Baumgard ML, Hattier T, Davis T, Frye C, Hu R, Swedlund B, Teng DH, Tavtigian SV (1997): Identification of a candidate tumour suppressor gene, MMAC1, at chromosome 10q23.3 that is mutated in multiple advanced cancers. Nat Genet 15:356-62.

Steenbergen RD, Hermsen MA, Walboomers JM, Joenje H, Arwert F, Meijer CJ, Snijders PJ (1995): Integrated human papillomavirus type 16 and loss of heterozygosity at 11q22 and 18q21 in an oral carcinoma and its derivative cell line. Cancer Res 55:5465-71.

Steinberg BM, DiLorenzo TP (1996): A possible role for human papillomaviruses in head and neck cancer. Cancer Metastasis Rev 15:91-112.

Strome SE, Savva A, Brissett AE, Gostout BS, Lewis J, Clayton AC, McGovern R, Weaver AL, Persing D, Kasperbauer JL (2002): Squamous cell carcinoma of the tonsils: a molecular analysis of HPV associations. Clin Cancer Res 8:1093-100.

Su JY, Erikson E, Maller JL (1996): Cloning and characterization of a novel serine/threonine protein kinase expressed in early Xenopus embryos. J Biol Chem 271:14430-7.

Syrjänen K, Syrjänen S (2000): Papillomavirus Infections in Human pathology. London: John Wiley \& Sons, Ltd.

Syrjänen K, Syrjänen S, Lamberg M, Pyrhönen S, Nuutinen J (1983a): Morphological and immunohistochemical evidence suggesting human papillomavirus (HPV) involvement in oral squamous cell carcinogenesis. Int J Oral Surg 12:418-24. 
Syrjänen K, Syrjänen S, Pyrhönen S (1982): Human papilloma virus (HPV) antigens in lesions of laryngeal squamous cell carcinomas. ORL J Otorhinolaryngol Relat Spec 44:323-34.

Syrjänen KJ, Pyrhönen S, Syrjänen SM (1983b): Evidence suggesting human papillomavirus (HPV) etiology for the squamous cell papilloma of the paranasal sinus. Arch Geschwulstforsch 53:77-82.

Syrjänen S (2004): HPV infections and tonsillar carcinoma. J Clin Pathol 57:449-55.

Syrjänen S, Puranen M (2000): Human papillomavirus infections in children: the potential role of maternal transmission. Crit Rev Oral Biol Med 11:259-74.

Thierry F, Howley PM (1991): Functional analysis of E2-mediated repression of the HPV18 P105 promoter. New Biol 3:90-100.

Thomas M, Laura R, Hepner K, Guccione E, Sawyers C, Lasky L, Banks L (2002): Oncogenic human papillomavirus E6 proteins target the MAGI-2 and MAGI-3 proteins for degradation. Oncogene 21:5088-96.

Thorland EC, Myers SL, Persing DH, Sarkar G, McGovern RM, Gostout BS, Smith DI (2000): Human papillomavirus type 16 integrations in cervical tumors frequently occur in common fragile sites. Cancer Res 60:5916-21.

Tominaga S, Fukushima K, Nishizaki K, Watanabe S, Masuda Y, Ogura H (1996): Presence of human papillomavirus type $6 \mathrm{f}$ in tonsillar condyloma acuminatum and clinically normal tonsillar mucosa. Jpn J Clin Oncol 26:393-7.

UICC (2002): TNM Classification of Malignant Tumours. New York: Wiley-Liss.

Ustav M, Ustav E, Szymanski P, Stenlund A (1991): Identification of the origin of replication of bovine papillomavirus and characterization of the viral origin recognition factor E1. Embo J 10:4321-9.

van Houten VM, Snijders PJ, van den Brekel MW, Kummer JA, Meijer CJ, van Leeuwen B, Denkers F, Smeele LE, Snow GB, Brakenhoff RH (2001): Biological evidence that human papillomaviruses are etiologically involved in a subgroup of head and neck squamous cell carcinomas. Int J Cancer 93:232-5.

Watanabe S, Ogura H, Fukushima K, Yabe Y (1993): Comparison of Virapap filter hybridization with polymerase chain reaction and Southern blot hybridization methods for detection of human papillomavirus in tonsillar and pharyngeal cancers. Eur Arch Otorhinolaryngol 250:115-9. 
Weijerman PC, van Drunen E, Konig JJ, Teubel W, Romijn JC, Schroder FH, Hagemeijer A (1997): Specific cytogenetic aberrations in two novel human prostatic cell lines immortalized by human papillomavirus type 18 DNA. Cancer Genet Cytogenet 99:108-15.

Veldman T, Liu X, Yuan H, Schlegel R (2003): Human papillomavirus E6 and Myc proteins associate in vivo and bind to and cooperatively activate the telomerase reverse transcriptase promoter. Proc Natl Acad Sci U S A 100:8211-6.

Werness BA, Levine AJ, Howley PM (1990): Association of human papillomavirus types 16 and 18 E6 proteins with p53. Science 248:76-9.

Wiest T, Schwarz E, Enders C, Flechtenmacher C, Bosch FX (2002): Involvement of intact HPV16 E6/E7 gene expression in head and neck cancers with unaltered p53 status and perturbed pRb cell cycle control. Oncogene 21:1510-7.

Wilczynski SP, Lin BT, Xie Y, Paz IB (1998): Detection of human papillomavirus DNA and oncoprotein overexpression are associated with distinct morphological patterns of tonsillar squamous cell carcinoma. Am J Pathol 152:145-56.

Wilke CM, Hall BK, Hoge A, Paradee W, Smith DI, Glover TW (1996): FRA3B extends over a broad region and contains a spontaneous HPV16 integration site: direct evidence for the coincidence of viral integration sites and fragile sites. Hum Mol Genet 5:187-95.

Zerfass-Thome K, Zwerschke W, Mannhardt B, Tindle R, Botz JW, Jansen-Durr P (1996): Inactivation of the cdk inhibitor p27KIP1 by the human papillomavirus type 16 E7 oncoprotein. Oncogene 13:2323-30.

Zhang B, Spandau DF, Roman A (2002): E5 protein of human papillomavirus type 16 protects human foreskin keratinocytes from UV B-irradiation-induced apoptosis. J Virol 76:220-31.

Zhang P, Steinberg BM (2000): Overexpression of PTEN/MMAC1 and decreased activation of Akt in human papillomavirus-infected laryngeal papillomas. Cancer Res 60:1457-62.

Zheng J, Saksela O, Matikainen S, Vaheri A (1995): Keratinocyte growth factor is a bifunctional regulator of HPV16 DNA-immortalized cervical epithelial cells. J Cell Biol 129:843-51. 
Zheng J, Vaheri A (1995): Human skin fibroblasts induce anchorage-independent growth of HPV-16-DNA-immortalized cervical epithelial cells. Int J Cancer 61:658-65.

Zheng J, Wahlström T, Paavonen J, Vaheri A (1994): Altered growth behavior of human cervical epithelial cells transfected by HPV type 16 and 18 DNA. Int J Cancer 58:713-20.

Zumbach K, Hoffmann M, Kahn T, Bosch F, Gottschlich S, Gorogh T, Rudert H, Pawlita M (2000): Antibodies against oncoproteins E6 and E7 of human papillomavirus types 16 and 18 in patients with head-and-neck squamouscell carcinoma. Int J Cancer 85:815-8.

zur Hausen H (1976): Condylomata acuminata and human genital cancer. Cancer Res 36:794.

zur Hausen H (1996): Papillomavirus infections--a major cause of human cancers. Biochim Biophys Acta 1288:F55-78.

zur Hausen H (1999a): Papillomaviruses in human cancers. Proc Assoc Am Physicians 111:581-7.

zur Hausen H (1999b): Viruses in human cancers. Eur J Cancer 35:1174-81.

zur Hausen H, Meinhof W, Scheiber W, Bornkamm GW (1974): Attempts to detect virus-secific DNA in human tumors. I. Nucleic acid hybridizations with complementary RNA of human wart virus. Int J Cancer 13:650-6. 
ISSN 1457-8433

ISBN 952-10-1911-5 (Paperback)

ISBN 952-10-1912-3 (PDF)

Edita Prima Oy

Helsinki, 2004 